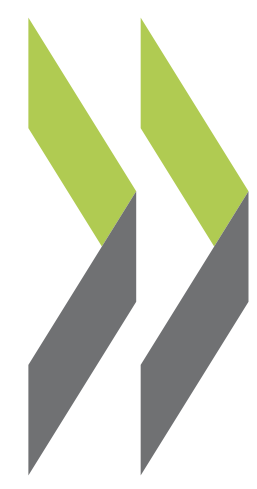

OECD Working Papers on International Investment 2021/01

Assessing the effectiveness

of currency-differentiated tools: The case of reserve requirements
Annamaria de Crescenzio,

Etienne Lepers, Zoe Fannon 


\title{
OECD WORKING PAPERS ON INTERNATIONAL INVESTMENT
}

OECD Working Papers should not be reported as representing the official views of the OECD or of its member countries. The opinions expressed and arguments employed are those of the authors.

Working Papers describe preliminary results or research in progress by the author(s) and are published to stimulate discussion on a broad range of issues on which the OECD works. Comments on Working Papers are welcomed, and may be sent to investment@oecd.org or the Investment Division, Directorate for Financial and Enterprise Affairs, OECD, 2 rue André-Pascal, 75775 Paris Cedex 16, France.

\section{OECD WORKING PAPERS ON INTERNATIONAL INVESTMENT}

are published on

\author{
www.oecd.org/investment/working-papers.htm
}

This document and any map included herein are without prejudice to the status of or sovereignty over any territory, to the delimitation of international frontiers and boundaries and to the name of any territory, city or area.

(C) OECD 2021

\footnotetext{
You can copy, download or print OECD content for your own use, and you can include excerpts from OECD publications, databases and multimedia products in your own documents, presentations, blogs, websites and teaching materials, provided that suitable acknowledgment of OECD as source and copyright owner is given. All requests for commercial use and translation rights should be submitted to rights@oecd.org
} 


\title{
Assessing the effectiveness of currency-differentiated tools: \\ The case of reserve requirements
}

\author{
Annamaria de Crescenzio, Etienne Lepers and Zoe Fannon ${ }^{1}$
}

\begin{abstract}
This paper provides the first comprehensive analysis of benefits and side-effects of foreigncurrency differentiated reserve requirements for a sample of 58 countries from 1999 to 2015 . Departing from the existing literature on effectiveness which used binary variables to measure policy changes, the intensity of reserve requirement adjustments is captured by using the gap between foreign and local currency rates to isolate the impact of differentiation net of volume effects.

The findings show that increasing the gap between FX and local currency-denominated reserve requirements is generally effective in reducing currency mismatch and dollarisation in banks' balance sheets, notably through a reduction in the share of banks' FX liabilities to total liabilities and in banks' net FX positions. The findings also show that a higher gap is associated with a broader reduction in capital inflows, in particular portfolio debt inflows and flows to non-banks. Little evidence of domestic or international circumvention, with risks shifting to other sectors or countries is visible.
\end{abstract}

Authorised for release by Greg Medcraft, Director, OECD Directorate for Financial and Enterprise Affairs Keywords: macro-prudential policies, differentiated reserve requirement, currency mismatch, banking regulation, dollarisation.

JEL Classification: E58, F3, F38, G28

\footnotetext{
${ }^{1}$ Annamaria de Crescenzio and Etienne Lepers are economists within the OECD Directorate for Financial and Enterprise Affairs; Zoe Fannon is at Somerville College, University of Oxford (United Kingdom). The authors are grateful to Winfrid Blaschke, Annamaria Kokenyne, Ana Novik, Gurnain Pasricha, Enes Sunel as well as delegates of the Advisory Task Force on the Codes for their comments, and to Ernesto Murillo León (Colombia's Financial Superintendence), Zine Mshengu (South Africa's Central Bank) for sharing relevant data.
} 



\section{Table of contents}

1. Introduction $\quad 7$

2. Reserve requirements inside out 9

Features 9

From monetary to macroprudential objectives, the changing use of reserve requirements $\quad 10$

Costs and benefits of currency differentiated reserve requirements: a conceptual framework $\quad 14$

3. Empirical model and data 16

4. Results 19

$\begin{array}{ll}\text { Direct effect on outcomes variables } & 19\end{array}$

Domestic side-effects $\quad 20$

International externalities $\quad 22$

5. Robustness checks 23

Alternative method to control for endogeneity 23

Does the effect of changes in reserve requirements depend on the initial level of the rate? $\quad 24$

6. The value of intensity-based measures 25

7. Policy implications and possible areas of future work 27

$\begin{array}{ll}\text { References } & 28\end{array}$

Annex A. Supplementary materials 32

Annex B. OECD Working Papers on International Investment $\quad 45$

Tables

Table 1 - Direct effect of changes in reserve requirements $\quad 19$

Table 2 - Indirect effects of changes in reserve requirements 21

Table 3 - The direct effect of reserve requirements: intensity-based measures vs. easing/tightening binary 26
variables

Table 4 - The indirect effect of reserve requirements: intensity-based measures vs. easing/tightening binary variables

Table A 1: Variable descriptions $\quad 35$

Table A 2 - Summary Statistics $\quad 36$ 
6

Table A 3 - Direct effect of changes in reserve requirements $\quad 37$

Table A 4 - Indirect effect of changes in reserve requirements 38

Table A 5 - Testing for international spillover following tightening in FX reserve requirements 39

Table A 6 - First stage regressions (Drivers of RR adjustments) 40

Table A 7 - Direct and indirect effect - the residual method $\quad 41$

Table A 8 - Non linear models $\quad 42$

Table A 9 - The direct effect of reserve requirements: intensity-based measures vs. easing/tightening binary variables

Table A 10 - The indirect effect of reserve requirements: intensity-based measures vs. easing/tightening binary variables

\section{Figures}

Figure 1 - Average reserve requirement ratio (1999-2019) 10

Figure 2. RR currency-differentiation (2015) 12

Figure 3. Liabilities included in the reserve base (2015)

Figure 4 - Regional use of currency-differentiated and undifferentiated RR (1999-2019) 13

Figure A 1: Adjustments in single reserve requirements 33

Figure A 2 - Adjustments in reserve requirements on FX liabilities $\quad 34$ 


\section{Introduction}

The post-financial crisis period has seen a proliferation of the use of macroprudential tools, designed to both mitigate the build-up of vulnerabilities and increase the resilience of the financial system. However, since the 2008 crisis, new vulnerabilities have emerged, such as the increasing foreign exchange (FX) debt by Emerging Market Economies (EMEs) which has contributed to the rise of currency mismatches in banks and corporates' balance sheets (Chui, Kuruc and Turner, 2016 $\left.{ }_{[1]}\right)$. These developments have restarted a debate on the role of the exchange rate in driving financial conditions and the appropriate toolkit to deal with large exchange rate swings (Carstens, 2019 ${ }_{[2]}$ ). Targeted macroprudential tools may help on this front, when ensuring liquidity buffers for bad times or reducing the FX exposure of different actors. In fact, "currency-based measures" (CBMs), i.e. measures that apply less favourable treatment on the basis of the currency of an operation have proliferated in the post-crisis period (de Crescenzio, Golin and Ott, $\left.2015_{[3]}\right)$. The few recent empirical studies on this category of policies point to their effectiveness in reducing credit growth (Lepers and Mehigan, 2019 ${ }_{[4]}$ ) or banks FX exposure (Ahnert et al., 2018[5]). On the other hand, CBMs may act de facto as measures hindering capital flows insofar as most of cross-border inflows are denominated in foreign currency (de Crescenzio, Golin and Molteni, 2017 $[6]$ ) or shift the risks from banks to other sectors (Ahnert et al., 2018[5] $)$. As such, it is important that costs and benefits of each measure are carefully assessed.

This paper contributes to these efforts by assessing the effectiveness of one of such tools, reserve requirements (RRs) applied to banks' liabilities, with a focus on foreign-currency differentiated ones, providing the first comprehensive analysis of the costs and benefits of such instrument across a large sample of countries.

Reserve requirements are an interesting policy tool to study for several reasons: First, the use of reserve requirements with a macroprudential intent has gained significant traction in recent years. They have become an important part of the policy instruments used to lean against the wind, mitigating credit cycle, notably in the Latin American region (Terrier et al., 2011 [7]; Lim et al., 2011 ${ }_{[8]}$ ). This is even more the case for currency-differentiated RRs (OECD, 2019[9]) imposing a higher rate on FX liabilities as they may directly target currency mismatches and deposit and loan dollarisation of the financial system - a common problem in several Latin American economies.

Second, the specific properties of reserve requirements - flexibility and experience - make them an appropriate countercyclical instrument (Agénor, Alper and Pereira da Silva, 2018[10]; Landau, 2018[11]). Reserve requirements were indeed part of the policy response to the 2020 COVID-19 crisis in countries that had been experiencing significant outflows: FX reserve requirements were cut in several countries to ensure easier access to liquidity (OECD, 2020[12]).

Finally, from an empirical point of view, reserve requirements present several advantages over other macroprudential tools: they have been the most frequently used tool in the last decades, allowing sufficient observations of policy adjustments to conduct meaningful econometric analyses and are more easily comparable across countries than other tools.

Departing from traditional studies on effectiveness using binary indicators, we directly use reserve requirement rates and are thus able to decompose a composition effect (gap between FX and LC rate) and a volume (average rate) and to provide economic magnitude for the impact of policy changes. 
Specifically, we test the impact of a change in the currency gap on a number of macroeconomic variables of interest:

First, we find that a higher gap between $\mathrm{FX}$ and local currency reserve requirements appears effective in reducing currency mismatch and dollarization in banks' balance sheets, proxied by the share of banks' FX liabilities to total liabilities and the net FX position of the banking sector. We find that a 1 percentage point increase in the gap between FX and LC rates leads to a 0.12 and 1.6 percentage point decrease in these respective variables over one year, and reaching 0.2 and 2.3 in models controlling better for potential endogeneity.

Second, a higher gap appears to have a negative impact on capital inflows more broadly, notably inflows to non-banks and portfolio debt inflows. We find that a 1 percentage point increase in the gap between FX and $L C$ rate leads to a reduction of portfolio debt inflow to GDP of 0.25 percentage point over a one year horizon. This is in line with previous studies on the impact of currency based measures on capital flows (de Crescenzio, Golin and Molteni, 2017[6]; Lepers and Mehigan, 2019 [4]]; Ahnert et al., 2018[5]). An increase in the gap is also associated with lower capital inflows to non-banks, albeit of smaller magnitude.

Third, we find little evidence of domestic circumvention through higher international debt issuance by corporates or higher cross-border flows to corporates, nor international circumvention.

Controlling for endogeneity creating proxies for 'exogenous' changes in reserve requirements, we find that all our previously significant results are confirmed and stronger evidence for the type of transmission mechanisms highlighted in our conceptual framework. Namely we find that a higher reserve requirement gap leads to lower cross-border flows to domestic banks, consistent with a shift away from foreign currency funding. We also test for evidence of non-linearity in the effect of changes in reserve requirement rates depending on the initial level of the rate: while our baseline results are robust to non-linearity hypothesis, we do find some support for the hypothesis that the higher the initial reserve requirement rate, the lower the impact of a change in the gap suggesting diminishing marginal effectiveness.

Overall, this paper contributes to the broader literature on the effectiveness of macroprudential tools by providing a detailed analysis of benefits and potential externalities through domestic and international circumvention of currency-differentiated reserve requirements. It also represents to our knowledge the first study capturing the intensity of reserve requirements, hence adding to studies trying to get closer to intensity (Eller et al., 2020[13]). Comparing our intensity-based results to results from a more classical binary policy indicator reveals significant differences, highlighting the necessity to better capture the intensity of policy measures in effectiveness studies.

Our results have important implications for policymakers: as for other macroprudential measures, there are important trade-offs in using differentiated reserve requirements. The measure appears to achieve several of its declared objectives, and in particular appears to be an effective tool against dollarization and currency mismatch. On the other hand, this paper finds that their use may also have broader indirect effects on capital flows. The impact of differentiated reserve requirements on cross-border flows is of particular interest to fora like the Advisory Task Force on the OECD Codes of Liberalisation. In particular, as they may have the features of capital flow management measures, the use of differentiated reserve requirements should be analysed in the framework of international agreements, such as the OECD Codes of Liberalisation for adhering countries. ${ }^{2}$ Dialogue on these measures should therefore continue to better understand pros and cons.

The remainder of the paper is structured as follows: Section 2 describes the features and motivation of reserve requirements and a conceptual framework to explain possible channels; Section 3 presents the

\footnotetext{
${ }^{2}$ In relation to international co-operation, in the last review of the OECD Codes of Liberalisation differentiated reserve requirements have been considered as measures whose conformity vis-à-vis the OECD Codes has to be assessed on a case by case basis. See here for further details on the revised instrument.
} 
empirical model and the data used; Section 4 describes the results for the direct impact, and the domestic and international side effects. Section 5 presents robustness checks relative to endogeneity and nonlinearity of the effect; Section 6 shows the importance of intensity based measures compared to binary policy indicators. Section 7 concludes by presenting policy conclusions and outlining avenues for further research.

\section{Reserve requirements inside out}

\section{Features}

Reserve requirements generally apply to deposit-taking institutions, to hold minimum reserves against their liabilities ("the reserve base"), usually in the form of balances at the central bank, the minimum reserves being calculated as a percentage of the targeted bank liabilities ("the reserve ratio").

Beyond this basic definition, there is a wide range of reserve requirements across countries, which arise from the numerous technical choices which have to be made in designing such tools. Apart from the ratio, central banks have to decide whether and to what extent the funds reserved at the central bank are remunerated, which are the eligible reserve assets (deposits, vault cash, T-bills), what is the currency of maintenance of the reserves (any, local or foreign currency) (See (OECD, 2019 ${ }_{[9]}$; Gray, 2011 [14]) for a detailed discussion).

Central banks also have to decide the scope of liabilities that are covered by the reserve requirements: are reserves required simply on deposits, a broader, or the full scope of a bank's financial liabilities, including loans and debt securities. Authorities may also exempt some liabilities from reserve requirements: e.g. government deposits, acting therefore as a subsidy for that particular type of liability.

Ratios can be further differentiated depending on the maturity of such liabilities, e.g. charging a higher rate on more volatile, shorter term liabilities.

Most importantly for the purpose of the present paper, reserve ratios may be differentiated depending on the currency denomination of the liabilities, with a lower or higher rate on foreign currency liabilities compared to local currency liabilities.

From a policymaker's perspective, one important benefit of reserve requirements is the relative ease of their use, in part because Central Banks have had decades of experience with reserve requirements when these tools were used as an integral part of the monetary policy toolkit and as micro-prudential buffers. In most places, the Central Bank has authority over the tool and it can adjust the ratio rapidly and flexibly.

Our data on reserve requirements mainly comes from the compilation efforts of Federico et al (2015), enhanced with an OECD survey to members (OECD, 2019 $\left.{ }_{[9]}\right)$ and complemented with country-specific research. The final sample used for our empirical analysis is an unbalanced panel of maximum 58 countries from $1999 q 1$ to $2015 q 3$. Country sample and quarterly adjustments in RR are displayed in Figure A1 and Figure A2. 


\section{From monetary to macroprudential objectives, the changing use of reserve requirements}

Reserve requirements have been part of the monetary toolkit for a long time, as a complement to, if not a substitute for, monetary policy adjustment of the interest rates, and in some countries have been a key component of a financially repressed economy (McKinnon, 1973 ${ }_{[15]}$ ). There has since been a significant evolution over time regarding the role of reserve requirements, which evolved from a purely monetary policy instrument to a diverse set of uses including based on financial stability motivations.

Figure 1 illustrates average reserve requirements ratios in Advanced Economies (AEs) and EMEs since the 2000s, highlighting a clear divide between EMEs and AEs: their use has declined in AEs, with the level of the ratios going down as countries reduce significantly or repeal their reserve requirement framework. EMEs, on the other hand, have tended to use reserve requirements more actively, with an increasing trend in the run-up to the 2008 crisis, followed by a reduction post-2008, after which it oscillated around more or less a stable average. The difference in average ratios between the two groups is also striking, with $11 \%$ on average for EMEs and $1.5 \%$ for advanced economies.

Figure 1 - Average reserve requirement ratio (1999-2019)

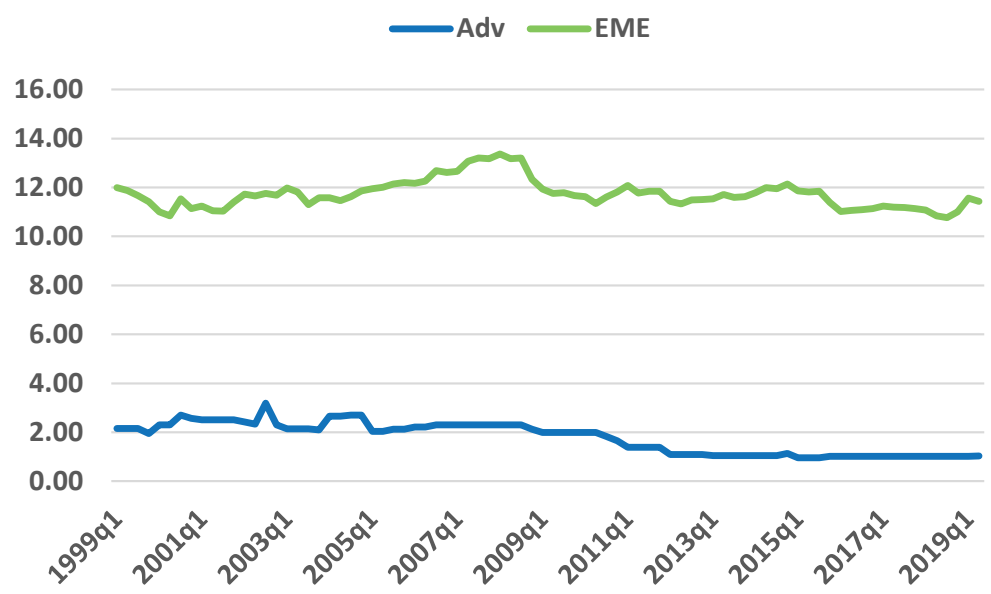

Source: Authors' calculations and data, notably based on Federico, Vegh, and Vuletin, (2015) and its 2019 update and OECD (2019) Note: Simple average of reserve requirement ratios. Advanced/Emerging classification based on IMF WEO groupings. 3

Reserve requirements were first used for microprudential purposes. Initially, they were to ensure that banks held a certain proportion of liquid assets as a buffer. This prudential purpose is likely outdated, following implementation of a series of financial regulations, and notably the Basel framework.

They were and are still used for monetary control purposes and adjusted, similarly to monetary policy, along the business cycle, e.g. to offset below trend output growth (Federico, Vegh and Vuletin, 2014[16]). The channel works through controlling reserves to affect credit growth, and indirectly amounts to a change

\footnotetext{
3 The sample comprises: Australia, Austria, Belgium, Canada, Chile, Czech Republic, Denmark, Estonia, Finland, France, Germany, Greece, Hungary, Iceland, Ireland, Israel, Italy, Japan, Latvia, Lithuania, Luxembourg, Mexico, Netherlands, New Zealand, Norway, Portugal, Singapore, Slovakia, Spain, Sweden, Switzerland, Turkey, United Kingdom, United States, Albania, Argentina, Bahamas, Bangladesh, Belarus, Belize, Brazil, Bulgaria, China, Colombia, Costa Rica, Croatia, Dominican Republic, Ecuador, Guatemala, India, Indonesia, Jamaica, Kenya, Malaysia, Pakistan, Peru, Philippines, Romania, Russia, South Africa, Sri Lanka, Thailand, Trinidad and Tobago, Uganda, Uruguay.
} 
in interest rates. Compared to central bank policy rate adjustments, however, raising reserve requirements is less likely to attract capital inflows if they incentivise banks to raise lending rates without raising deposit rates (Montoro and Moreno, 2011 [17]). Indeed, all else equal, an increase in the reserve requirement ratio increases the effective funding cost of funding for banks with no actual change in the deposit rate. Recent research found evidence that reserve requirements indeed work that way, leading to higher lending rates. In contrast, raising policy rates lead to both higher lending and deposit rates, hence potentially attracting capital inflows by increasing carry trade opportunities (Brei and Moreno, 2018 ${ }_{[18]}$ ). In addition, in contrast to interest rates, RRs may lead to exchange rate depreciation, which makes the balance sheet effects stronger and the tool more effective when firms borrow in foreign currency (Glocker and Towbin, 2012[19]).

More recently, however, reserve requirements have started to be used with new objectives and following macroprudential considerations. As mentioned, reserve requirements impact credit growth and they may be used with a macroprudential intent to dampen credit cycles when used counter-cyclically (Agénor, Alper and Pereira da Silva, 2018[10]; Mimir, Sunel and Taşkin, 2013[20]; Glocker and Towbin, 2012[21]). Studying theoretically the optimal mix of a typical short-term policy rate and reserve requirements in a policy rule that smooths out fluctuations in credit spreads over the cost of foreign borrowing, Mimir and Sunel (2019[22]) find that when the central bank finds it hard to use interest rates to lean against the wind for price-stability reasons, reserve requirements may be an effective additional tool to do so without forgoing substantial stabilization gains. Cantù et al $\left(2019_{[23]}\right)$ also finds that tightening single reserve requirements limits the likelihood of financial distress. Beyond mitigating credit growth, they may also in theory be used as countercyclical liquidity tool in ways that tools like the Liquidity Coverage Ratio (LCR) and Net Stable Funding Ratio (NSFR) cannot (Landau, 2018[11]).

Introducing a maturity differentiation would also help address issues of maturity mismatches, insofar as banks would lengthen the maturity of their funding structures if shorter-term liabilities are taxed more.

Perhaps the most common way through which reserve requirements are and have been used as part of the policy toolkit for macroprudential purposes is through differentiation by currency. A number of central banks choose to impose higher reserve requirements on FX liabilities than on those in domestic currency. This policy choice is usually aimed at addressing country-specific issues, such as discouraging the use of $\mathrm{FX}$ in the economy, e.g. fighting dollarisation, reducing currency risk in banks' balance sheets, and/or for the purpose of managing capital flows.

Figure 2 highlights the distribution of countries that have currency-differentiated reserve requirements, RR not differentiated by currency, and no or 0-rate reserve requirements. A vast majority of countries use low undifferentiated reserve requirements. Figure 3 highlights the distribution of countries which impose reserve requirements on deposit only, on short term liabilities, with less than 2 year original maturity, and on all liabilities. This heterogeneity in design may affect the below-described transmission channels for our expected effects but the empirical test is beyond the scope of this paper and more suited for micro-data analysis. 
Figure 2. RR currency-differentiation (2015)

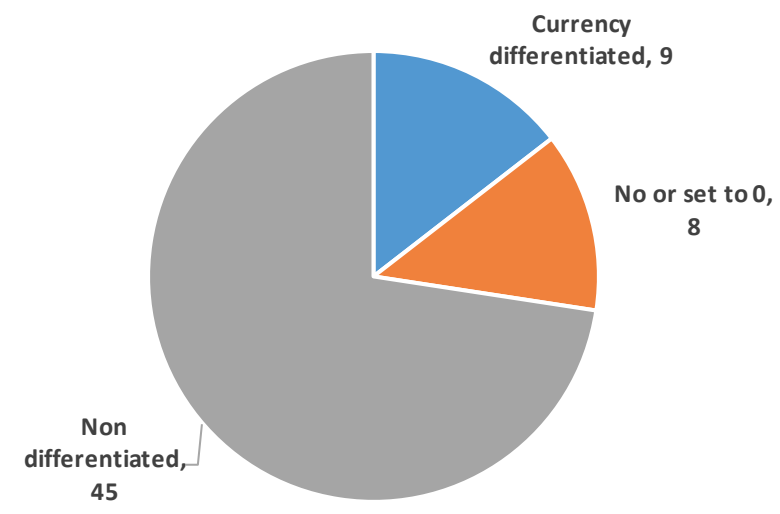

Note: The sample comprises the same sample as in Figure 1.

Source: Authors' calculations and data, notably based on Federico, Vegh, and Vuletin, (2015) and OECD (2019).

\section{Figure 3. Liabilities included in the reserve base (2015)}

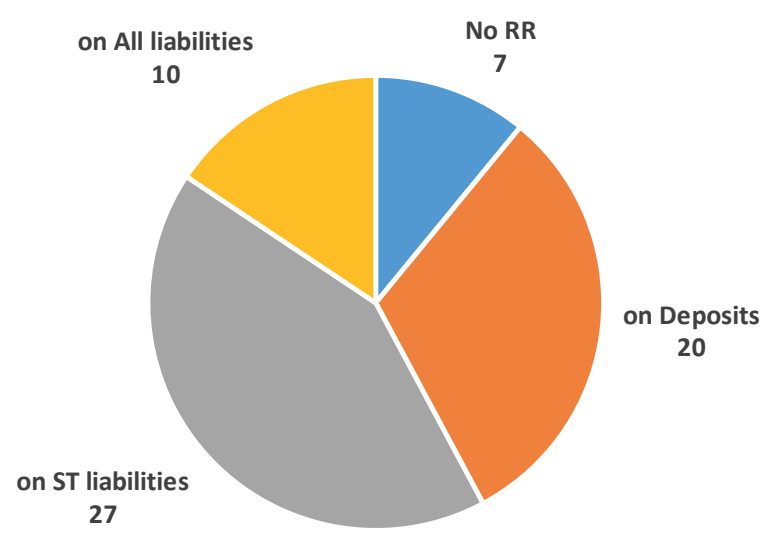

Note: Numbers in data label refer to the number of countries.

Source: Authors' calculations and data.

Looking at the regional breakdown, FX-differentiated reserve requirements have been widely used in Latin America, with countries like Peru and Argentina raising in the post-2008 crisis period their FX reserve requirements above $50 \%$ or $40 \%$, respectively. Countries like Brazil and Colombia adjust their undifferentiated reserve requirements, and countries like Chile and Mexico use a flat undifferentiated reserve requirement below $10 \%$. Asian economies employ undifferentiated reserve requirements, with China and the Philippines using them in the range of $20 \%$ and other economies in the region below $10 \%$. In the group "Emerging Europe", Turkey, Russia and Romania have been using differentiated reserve requirements, with the latter country raising it above $30 \%$ in the period preceding and following the 2008 crisis (Figure 4). 
Figure 4 - Regional use of currency-differentiated and undifferentiated RR (1999-2019)
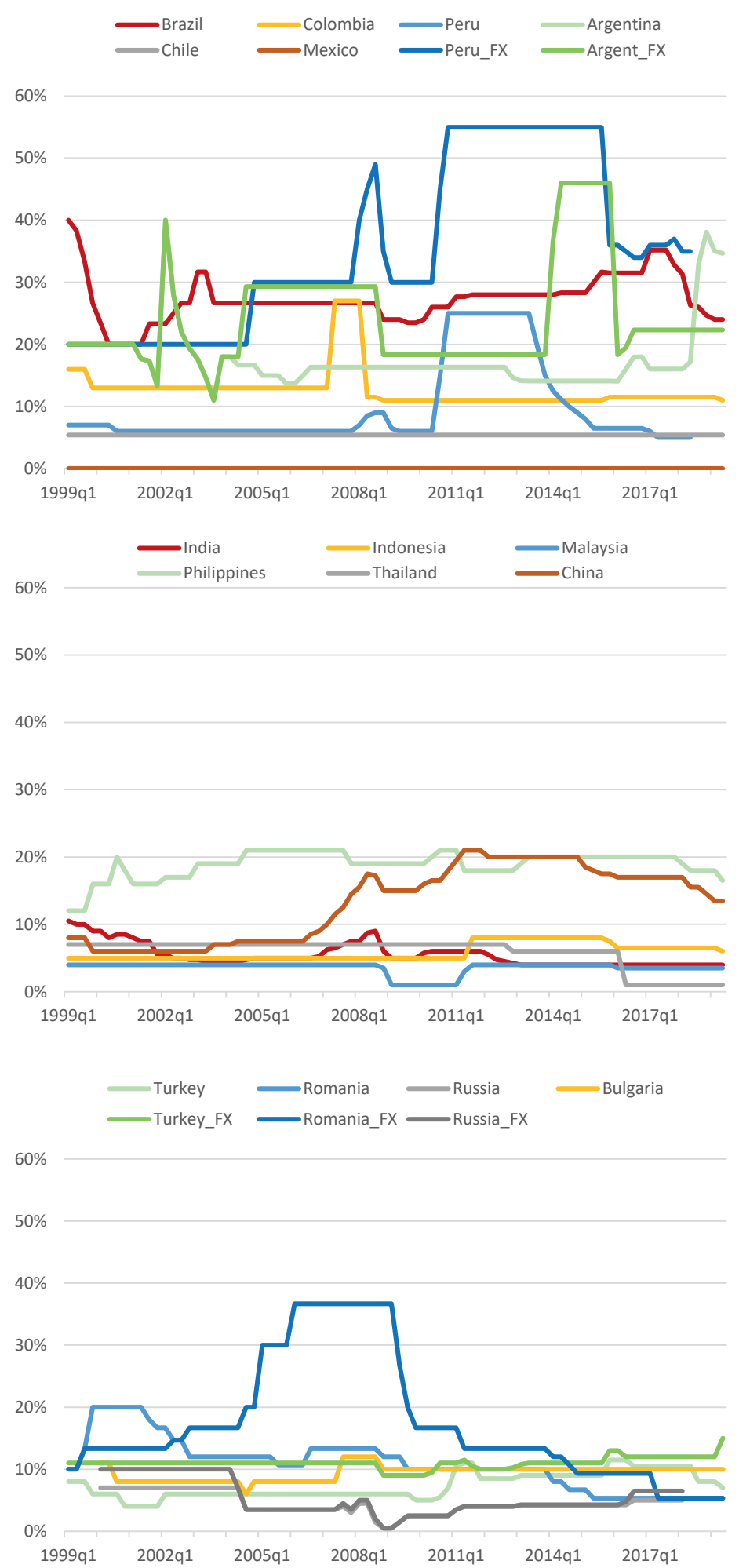

Source: Authors' calculations and data, based on Federico, Vegh, and Vuletin, (2014) and its 2019 update and OECD (2019). 
Costs and benefits of currency differentiated reserve requirements: a conceptual framework

\section{Channels}

Different reserve requirements may impact various financial stability outcomes through a number of channels (Figure 5).

\section{Figure 5 - Stylized transmission channels}

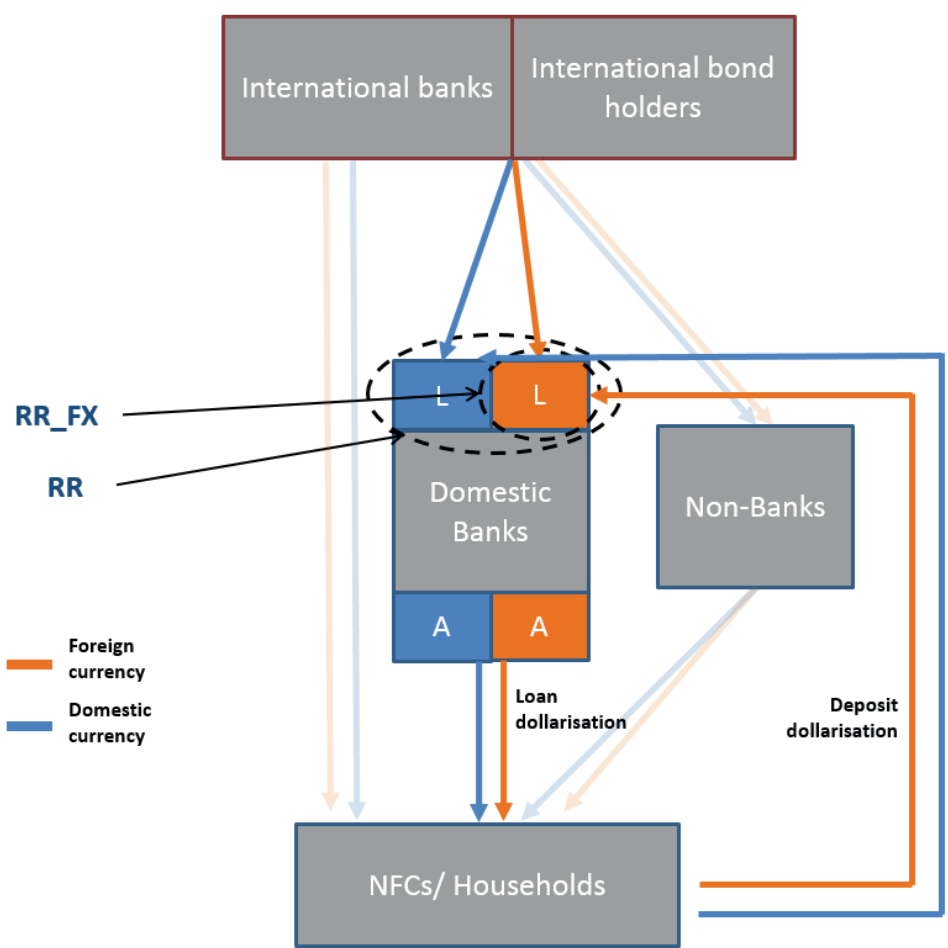

Note: The middle box represents a stylized bank balance sheet, with "A"= Assets, "L"=Liabilities. "NFCs"=Non-Financial Corporates. "RR"=Single reserve requirements, "RR_FX"= Reserve requirements differentiated by currency.

A core financial stability outcome is the capacity of reserve requirements to mitigate credit cycles. Single reserve requirements are reserve requirements with a single rate for all liabilities covered, which act akin to monetary policy rates and make funding for banks more costly across all liabilities covered by the requirements. This higher cost of funding would be the same whether these liabilities are to residents or non-residents. Through balance sheet effects, as the balance sheet of the bank shrinks, the asset side will also be impacted, and like interest rates, higher reserve requirements should lead to reduced credit growth, notably to domestic households and NFCs. This was most recently evidenced by Camors et al. (2019[24]), who thanks to firm level and credit registry data were able to test the impact on credit to the same firm, hence controlling for change in borrowers' characteristics.

When reserve requirements are differentiated by currency, with a higher ratio for FX liabilities than local currency liabilities, they will impact the volume and composition of the liabilities. Funding in foreign currency specifically will be more expensive - compared to local currency funding, incentivising banks to shift their funding mix toward local currency funding. A composition effect reflected in a reduced share of FX liabilities to total liabilities would be expected. In addition, such differentiation may also impact the origin of funds, potentially dis-incentivising external sources compared to domestic sources insofar, as cross border capital 
movements are usually denominated in foreign currency. It should thus have an impact on capital flows, as found in broader studies of currency-based measures (de Crescenzio, Golin and Molteni, 2017 [6]; Lepers and Mehigan, 2019 $9_{[4]}$; Frost, Ito and Van Stralen, 2020[25]).

Through similar balance sheet effects, there will be less funding available to extend FX loans on the asset side, which should be seen in a reduced share of FX loans or assets to total assets. Recent work, notably using credit registry or bank level data provides insights on some of the mechanisms: bank FX liabilities do feed credit dollarization (Özsöz, Rengifo and Kutan, 2015[26]), with banks' non-core FX liabilities feeding credit dollarization three times more than core FX liabilities according to a study on Turkey (Yılmaz, $\left.2020_{[27]}\right){ }^{4}$ The explanation may be related to the difference in maturity of non-core vs. core liabilities, the latter of which tend to be significantly shorter. ${ }^{5}$

Overall, FX-differentiated reserve requirements are thus expected to help countries with issues of dollarization on both the asset and liability sides. They may also reduce currency mismatches, with a better balance between FX assets and FX liabilities, as FX liabilities are used to fund FX assets.

\section{Externalities}

On the other hand, reserve requirements entail a number of externalities, which this paper also tests for. The basic cost of reserve requirements is that they effectively act as a distortive tax on bank funding (with differentiation imposing further disadvantages to specific operations). As such, they may move the activity and potential risk to non-regulated financial institutions, and may lead to financial disintermediation if calibrated excessively. The design of the reserve requirements is in this regard crucial, as banks will seek to use financial innovation to circumvent the requirement.

In the case of Brazil, Robitaille (2011[28]) argues that the reserve requirements induced banks to devise alternative funding sources: large banks were able to create repos to substitute for time deposits, while smaller banks were forced to increase risky loan portfolio sales. A recurrent finding in the literature on circumvention of macroprudential policy is that as macroprudential tools are usually applied to banks, the market gap may be filled by other financial institutions not covered by the policy (Aiyar, Calomiris and Wieladek, 2012[29]), and reserve requirements are no different.

If one focuses on credit to the private non-financial sector, notably domestic NFCs, three types of institutions may theoretically fill the gap left by banks: 1) non-financial institutions, 2) foreign branches when they are not covered by the reserve requirements, and 3) foreign banks or funds lending directly cross-border. ${ }^{6}$

With regards to FX exposure, the recent analysis by Ahnert et al. $\left(2018_{[5]}\right)$ demonstrate a transfer of the FX exposure and currency risk from banks to non-financial corporates. Banks reduce their exposure, but at the same time non-financial corporates increase FX debt issuance. Insofar as FX reserve requirements are expected to impact domestic FX credit growth to NFCs, a similar shift to international FX debt issuance by NFCs can be expected.

\footnotetext{
4 Traditional retail deposits are considered banks' core liabilities.

${ }^{5}$ In the case of Turkey, the average maturity of FX deposits held at Turkish banks is less than 3 months while it is as high as 68 months for syndicated loans (Yılmaz, 2020[27]).

${ }^{6}$ The relative strength of such channels would depend on the size of these different institutions and sectors in each country, as well as their participation in global capital flows. Non-bank financial institutions of advanced economies are for instance much more developed and integrated in the global financial system than the ones of emerging economies (See Lepers and Mercado (2020[52]) for stylized facts on sectoral capital flows in advanced and emerging economies).
} 
Finally, there may also be changes in the composition of credit portfolios of affected banks: there is recent evidence that, while bank credit diminishes when reserve requirements are increased, banks concentrate their portfolio in riskier firms (Camors, Peydró and Rodriguez-Tous, 2019[24]).

This paper analyses and quantifies the relative impact of an undifferentiated and FX-differentiated reserve requirements along these expected direct and indirect channels.

\section{Empirical model and data}

We seek to estimate the response of variables of interest to changes in reserve requirement rates.

A major limitation of the existing literature on CBMs is the reliance on binary variables such as tightening/easing variables, to measure policy changes ${ }^{7}$. A limitation of such an approach is that such binary variables fail to capture the intensity of policy changes: a tightening of an LTV cap from 90 to $60 \%$ would be coded exactly the same as a tightening from 90 to $6 \%$. This creates two problems: first, it provides no guidance on the optimal amount by which to change policy; and second, it would underestimate the impact of a one-off large change versus a series of small changes. ${ }^{8}$ These issues have led the most recent literature to move from aggregate indices to policy-specific studies, capturing both the intensity of the tool, as well as having a more precise identification of the transmission channels. These studies have so far focused on LTV ratios, which are comparable across countries (Richter, Schularick and Shim, 2019[30]; Alam et al., $\left.2019_{[31]}\right)$.

Our data enables us to get closer to the intensity of reserve requirements and provide information on the economic magnitude of the effects.

Let us consider the following model:

$$
\begin{aligned}
& Y_{i t}=\alpha+\sum_{k=0}^{3} \beta_{1, k}\left(\Delta R R_{i, t-k}^{F}-\Delta R R_{i, t-k}^{L}\right)+\sum_{k=0}^{3} \beta_{2, k} \Delta \text { average } R R_{i, t-k} \\
& +\sum_{k=0}^{3} \gamma_{L, k} R B M_{i, t-k}+\sum_{k=0}^{3} \gamma_{F, k} C B M_{i, t-k}+\sum_{k=0}^{3} \gamma_{L, k} M P M_{i, t-k}+\Gamma X_{i, t-1}+\delta_{i}+\delta_{T}+e_{i t}
\end{aligned}
$$

Changes in the reserve requirement rates are given by $\Delta R R_{i, t-k}^{L}, \Delta R R_{i, t-k}^{F}$ with the $L$ and $F$ superscripts representing the rates on local currency or foreign currency liabilities. While a model adding separately changes in these two rates would provide information on the effectiveness of increasing the rate of RR_L or RR_F in isolation, the economic rationale for the adjustment in currency-differentiated RR relies on the idea of the size of the gap between foreign and domestic currency liabilities and not on both rates

\footnotetext{
${ }^{7}$ For example, when a policy is tightened, an indicator-type variable takes the value +1 ; when policy is loosened, it takes -1 ; and if it there is no change, it takes 0 .

${ }^{8} \mathrm{~A}$ few papers have tried to get closer to the intensity of policies: an early attempt is Vandenbussche et al (2015[42]) and Eller et al $\left(2020_{[13]}\right)$, which tries in a study on Central and Eastern Europe to quantify the strength of different macroprudential tools.
} 
separately. Increasing the gap $\left(\Delta R R_{i, t-k}^{F}-\Delta R R_{i, t-k}^{L}\right)$ will be the key criterion for creditors for a shift away from FX funding to local currency funding.

This said, by simply looking at the differential, we overlook instances where the gap remains the same but reserve requirement rates are increased (or decreased) overall. The change in the overall average level of reserve requirements will have an impact on our outcome variables, which we ought to capture. We thus include the change in the average reserve requirement rate in the economy as additional variable $\left(\Delta\right.$ average $\left.R R_{i, t-k}\right)$ capturing all changes in levels, including from single reserve requirements. Overall, we thus narrow the diversity of reserve requirements in our country sample to 3 categories, three "rates": the rates on local or foreign currency liability for currency-differentiated RRs and the simple average reserve requirement rate. When RRs are further differentiated by the maturity of the liabilities, the average is computed. ${ }^{9}$ The following model makes it easier to grasp the benefits of differentiated RR and to interpret the results.

All variables are indexed by $i$ and $t$, identifying country and quarter, respectively.

The policy controls $R B M_{i, t-k}, C B M_{i, t-k}$, and $M P M_{i, t-k}$ represent adjustments in residency based measures (RBM), currency-based measures (CBM) and other macroprudential measures (MPM) which are all policies that may have an impact on our outcome variables. All of these variables are coded as +1 for each tightening or introduction of measure during the quarter, and -1 for each easing or removal of a measure during the quarter. Values may be higher than 1 and smaller than -1 in case several measures have been taken in the same policy category in the same quarter. The data mostly comes from OECD work: our data on capital controls/residency based measures (RBM) is from a new dataset collected in Lepers and Mehigan (2019 $\left.9_{[4]}\right)$, currency-based measures (CBM) is from de Crescenzio et al. $\left(2015_{[3]}\right)$ and Alam et al $\left(2019_{[31]}\right)$. Our data on other macroprudential tools (MPM) is from a recent IMF dataset (Alam et al., 2019[31]).

We also add a series of country-specific controls $X_{i, t-1}$ which have been found in previous literature to be important drivers of our outcome variables. While the specific set of controls varies depending on the outcome variables, they include real GDP growth (year on year), the domestic interest rate (or in some cases the differential between the domestic rate and the US interest rate ${ }^{10}$ ), growth in the real effective exchange rate, and sovereign ratings, and for exchange rate valuation proxies, we add capital inflows and the exchange rate regime. We lag all of our control variables by one quarter to limit endogeneity issues.

All variables are described in detail in Table A1 Summary statistics for our dependent and independent variables are provided in Table A2.

We scale all our flow variables by annual GDP as we interpret the effectiveness of RR changes over 4 quarters (see next section) but we calculate a 4 quarters moving average of annual GDP to avoid sharp changes from Q4 to Q1. All continuous variables have been symmetrically winsorised at the $2 \%$ level to limit outliers.

The choice of the lag structure for our policy variables is also worth discussing. While there has not been any previous study on the specific time after which a change in reserve requirement will have an impact,

\footnotetext{
${ }^{9}$ We recognize that in practice, the binding character of a reserve requirement framework depends on the relative financing structure of each bank and that as a result, a simple average is not ideal (an average weighted by the relative share of each type of liabilities would be necessary). This is the case at the country-level but also within each country at the bank-level (global banks vs. small local banks will have different funding structure). For simplicity, due to data constraints on even country-level funding structures and in light of the important diversity of reserve requirements settings across countries, we take a simple average.

${ }^{10}$ While we could have used not only the US rate, but also the JP, EU, CH, and UK interest rates as possible reference rates and weight them by the financial exposure of a specific country to these rates, such transformation undesirably reduces the country sample due to data availability on financial weights.
} 
we expect banks to react quickly to changes in reserve requirements. We decide to see the impact of reserve requirements over a year time and thus a [t,t-3] lag structure. Such lag structure was also chosen in recent studies on currency-based measures (Ahnert et al., 2018 $\left.{ }_{[5]}\right)$. While capturing the delay in the effectiveness of a policy over a reasonable time period, it also eases interpretation of the results. We take a similar lag structure for our other policy variables (CBM, RBM, MPM).

In addition, the specification includes country and year fixed effects $\delta_{i}$ and $\delta_{T}$. The fixed-effect regression approach was chosen because it helps us towards isolating the effect of the policy change on the variable of interest by controlling for confounding sources of variation. We thus control for consistent countryspecific differences in the outcome variables and for time-specific differences in the outcome variables, such as a widespread drop in NFC debt issuance during the financial crisis. The estimated coefficient on the policy change measure thus captures the extent to which variation in the outcome that is not due to country-specific or time-specific factors can be explained by the change in policy. The coefficient $\beta_{1}$ is interpreted as the magnitude of a change in the outcome variable in response to an increase in the difference between the $\mathrm{FX}$ and local currency reserve requirement rate of one percentage point. Year fixed effects were chosen over quarter fixed effects to limit the number of variables in the regression, already important with the lag structures of the policy variables. The error term is clustered by country but is assumed independent across countries. ${ }^{11}$

There may be a simultaneity bias: the coefficients $\beta_{1, k}$ and $\beta_{2, k}$ may be picking up the response of policy to changes in the variables of interest. This is somewhat addressed by our lag structure - we control for the effect of policy change within the last year (covering 4 quarters). We address the endogeneity issue more formally in the robustness section by conducting a two-step regression framework. Other models were considered such as Inverse Propensity Weighting (IPW) used in Alam et al. (2019 [31]) and Richter et al. $\left(2019_{[30]}\right)^{12}$ or dynamic and system GMM approaches ${ }^{13}$, but none allowed us to address the simultaneity bias and relax the assumption that policy responds with a lag without introducing alternative assumptions deemed undesirable.

\footnotetext{
${ }^{11}$ We do not include a lagged dependent variable as tests did not display significant persistence of our outcome variables, its inclusion does not change the results.

${ }^{12}$ As noted by Jorda and Taylor (2016[49] $)$, IPW does not address simultaneity bias. IPW will reduce the risk of bias due to the omission of other important explanatory variables from the model. It is akin to the inclusion of control variables in a regression, with the benefit of being non-parametric and the limitation that it can only be used where the explanatory variable is categorical. While controlling for omitted variable bias is important, we prefer in our baseline model to control for omitted variable bias by simply testing various control variables in the main specification since a key contribution of our paper is to use a non-categorical explanatory variables.
}

${ }^{13}$ We did not use dynamic and system GMM approaches, often used to address simultaneity in panel applications, for two reasons. First, our data structure is such that the panel dimension $\mathrm{N}$ (the number of countries) and the time dimension $\mathrm{T}$ (the number of quarters) are similar and reasonably large, while GMM methods are intended for datasets with large $\mathrm{N}$ and small $\mathrm{T}$ (Blundell and Bond, 2000[51]). When $\mathrm{T}$ is relatively large, as is the case in our data, there is an instrument proliferation problem which biases the GMM coefficient estimates towards the non-instrumented panel estimates and causes statistical tests for mis-specification to be weak (Roodman, 2009[50]). The second problem is with the lag structure. GMM requires that lagged values of the explanatory variable do not affect the outcome, but we assume that reserve requirement changes can affect outcome variables with up to four quarters' lag. One could use the fifth lag and earlier as instruments for the first lag, but the strong persistence of the explanatory variable required to justify that assumption may itself contribute to the dynamic GMM weak instrument problem (Blundell and Bond, $2000_{[51]}$ ) and imply a violation of the additional condition required for system GMM (Roodman, 2009[50]). 


\section{Results}

\section{Direct effect on outcomes variables}

Following the conceptual framework outlined in Section 2.3, we first test the effectiveness of reserve requirements on a series of variables.

Our outcome variables are the following: 1) total inflows to domestic banks; 2 ) the share of FX loans to total assets; 3) the share of FX liabilities to total liabilities; 4) the net FX position of the banking sector. ${ }^{14}$

Results are summarised focusing on our variables in Table 1, while full results are provided in Table A3 in the Annex. For ease of interpretation of the results, we follow Ahnert et al. (2019) in taking the sum of the coefficients of the four lags [t,t-3] and test whether the sum of all four coefficients is significantly different from zero ( $p$ value instead of standards errors are displayed in the table for reserve requirements coefficients, and italic is used to differentiate with other coefficients in Table A3). Such method allows us to summarise the information provided by the four separate coefficients.

\section{Table 1 - Direct effect of changes in reserve requirements}

\begin{tabular}{|c|c|c|c|c|}
\hline & $\begin{array}{l}\text { Inflows } \\
\text { to banks }\end{array}$ & $\begin{array}{l}\Delta \mathrm{FX} \\
\text { loans } \\
\text { share }\end{array}$ & $\begin{array}{c}\Delta \mathrm{FX} \text { liab } \\
\text { share }\end{array}$ & $\begin{array}{l}\Delta \text { Net FX } \\
\text { position }\end{array}$ \\
\hline$\overline{G a p}\left(\Delta R R \_F-\Delta R R \_L\right)(t, t-4)$ & -0.10 & -0.23 & $-0.111^{*}$ & $-1.62^{* * *}$ \\
\hline $\mathrm{N}$ & 2,773 & 891 & 1,029 & 797 \\
\hline Countries & 49 & 25 & 29 & 35 \\
\hline
\end{tabular}

Regarding controls, GDP growth is generally associated with higher flows, as is higher sovereign ratings. Interest rate and interest rate differential display little significance. Finally, depreciation of the effective exchange rate is associated with a higher share of FX loans in bank balance sheets overall.

The respective effects of macroprudential, currency-based, and capital control measures deserve detailed explanations beyond the scope of this paper and have been the object of Lepers and Mehigan (2019[4]). They are used here as controls while our key focus is on reserve requirements.

Looking at the effects of the differential (the gap) between FX and local currency-denominated reserve requirements in Table 1:

\footnotetext{
14 Because data are collected from different sources, the size of the sample and the countries included vary across regression and hence coefficients are not comparable across regressions. We note this caveat while choosing to include each time the largest sample. We control for specific countries driving the results across regressions in the robustness checks.
} 
- On the currency composition of bank balance sheets, we find that a higher gap between FX and local currency reserve requirements reduces the share of FX liabilities to total liabilities, albeit not strongly (col. 3). Differentiated reserve requirements also appear very effective in reducing the net FX position ratios (col. 4). Specifically, a 1 percentage point increase in the gap between FX and LC rate leads to a 0.1 percentage point reduction in the share of FX loans to total loans and a 1.6 percentage point reduction in the net FX position over a year time (4 quarters) ${ }^{15}$. The coefficient on the share of FX loans is negative but insignificant (col 2). Reserve requirements are a liability side measure and would only impact the asset side through balance sheet effects which are thus indirect and may not be necessarily well captured through aggregate cross country analysis like these.

- On the cross-border side, the coefficient on total capital inflows to domestic banks is negative, as expected, but not statistically significant (col. 1). Data availability prevents us from splitting crossborder bank financing between local and foreign currency, as the relevant BIS data covers only a limited number of countries using FX RRs, and hence we prefer not to use the currency split. This may explain the lack of significance in the model, as our conceptual framework expects a cut in cross-border funding in foreign currency but not in local currency.

Finally, a relevant observation is that in practically all cases, the coefficients of the four lags go in the same direction, providing more certainty on the direction of the results and less scepticism regarding the fact that our results are driven by our somewhat arbitrary choice of lag structure.

Overall, introducing the differentiation in the rates seems to match the intended effects by central banks: we see a shift away from FX liabilities (albeit not large) and a significantly lower overall FX position, and hence a lower mismatch.

\section{Domestic side-effects}

Next, we turn to the identification of potential externalities, unintended effects, and evidence of circumvention of changes in FX reserve requirements.

We test 7 outcome variables: 1) the change in the issuance of international debt by NFCs; 2) capital inflows to non-banks; 3 ) total capital inflows across the three most volatile asset classes (portfolio equity, portfolio debt, other investment/credit flows) ${ }^{16} ; 4$ ) two measures of exchange rate deviation from trend.

A summary of the results is presented in Table 3 and full results are presented in Table A4 in the Annex.

\footnotetext{
${ }^{15}$ As we work with country level data, as for our other variables, our outcome variable is the net FX position of the banking sector as a whole. There may obviously be heterogeneity in the net FX position of individual banks which are not captured by the aggregate variable and by our results here. Firm level analysis could identify heterogeneous effect of reserve requirements across banks.

${ }^{16}$ By "inflows" we understand non-resident flows, i.e. the net incurrence of liabilities to non-residents. To account for the persistence in capital flows, we also try models with lagged dependent variable as regressor and the results do not change.
} 
Table 2 - Indirect effects of changes in reserve requirements

\begin{tabular}{|c|c|c|c|c|c|c|c|}
\hline & $\begin{array}{c}\text { NFC debt } \\
\text { growth }\end{array}$ & $\begin{array}{l}\text { Inflows } \\
\text { to non- } \\
\text { banks }\end{array}$ & $\begin{array}{l}\text { Equity } \\
\text { Inflows }\end{array}$ & $\begin{array}{c}\text { Debt } \\
\text { Inflows }\end{array}$ & $\begin{array}{l}\text { Other } \\
\text { Inflows }\end{array}$ & $\begin{array}{c}\text { Exchange } \\
\text { rate } \\
\text { Deviation } \\
3 Y\end{array}$ & $\begin{array}{c}\text { Exchange } \\
\text { rate } \\
\text { Deviation } \\
5 Y\end{array}$ \\
\hline$\overline{\text { Gap }\left(\Delta R R \_F-\Delta R R \_L\right)(t, t-4)}$ & 0.00 & $-0.078^{* *}$ & -0.025 & $-0.218^{* \star *}$ & -0.12 & 0.76 & -1.44 \\
\hline N & 2,826 & 2,773 & 2,702 & 2,703 & 2,763 & 2,545 & 2,196 \\
\hline Countries & 51 & 49 & 48 & 48 & 49 & 48 & 48 \\
\hline
\end{tabular}

Note: ${ }^{*} p<0.10,{ }^{* *} p<0.05,{ }^{* * *} p<0.01$

We find that:

- A higher gap is associated with a reduction in overall capital inflows (col. 3-5), with all coefficients being negative. However, only portfolio debt inflows appear statistically significant, at the $1 \%$ level. Specifically, a 1 percentage point increase in the gap leads to a reduction of portfolio debt inflow to GDP of 0.25 percentage point. As FX reserve requirements may cover bonds, but often cover neither interbank lending nor equity, the result may not be surprising.

- An increase in the gap is also associated with lower capital inflows to non-banks (column 2), significant at the $5 \%$ level, albeit of small magnitude. This appears as a side-effect, as according to our conceptual framework, the direct effect of a higher RR gap should lower capital inflows to banks, but not to non-banks. Notwithstanding the small size of the coefficient, this result may be surprising, as we may have expected a positive coefficient if NFCs seek to get the FX financing they cannot get from domestic banks directly cross-border. We do not find evidence of such circumvention and, on the contrary, this result points to a broader impact of FX reserve requirements on the domestic economy. ${ }^{17}$

- FX reserve requirements do not seem to have an impact, either, on exchange rate deviation from long term trends ( 3 or 5 years). However, further research using more sophisticated measures of exchange rate misalignments, notably deviations from model-based equilibrium exchange rate, could be done. ${ }^{18}$

- Finally, we find little evidence of circumvention of FX reserve requirements, i.e. with the private sector getting more funding from abroad ( $\mathrm{col} 1$ and 2 ) if it cannot receive the FX funds from domestic banks. Unlike Ahnert et al $\left(2018_{[5]}\right)$ who study a much broader set of currency-based measures, we do not find evidence of higher international debt issuance of corporates, and as mentioned above there is a negative rather than positive effect on inflows to non-banks.

Overall, our results on side-effects highlight two main conclusions: first, FX reserve requirements appear to affect overall cross-border inflows beyond a simple reduction of domestic banks' external financing. This is consistent with results on the impact of currency based measures on capital flows (Ahnert et al., 2018[5]; de Crescenzio, Golin and Molteni, 2017[6]; Lepers and Mehigan, 2019[4]; Frost, Ito and Van Stralen, $2020_{[25]}$, and provides evidence of an impact on capital flows for FX reserve requirements. Secondly, while many studies have highlighted important circumvention of macroprudential tools, we do not see evidence of circumvention in the case of $\mathrm{FX}$ reserve requirements on the variables studied here.

\footnotetext{
${ }^{17}$ One explanation for this result may be the negative signal that such adjustments send to international investors. In the case of adjustments of capital controls, Forbes et al (2016[32] $)$ show that a measure need not actually be binding on international investors for them to reduce investment in the country. This would be consistent with the small size of the coefficient.

${ }^{18}$ Loeffler $\left(2015_{[53]}\right)$ finds that single reserve requirements represent an efficient tool to depreciate the exchange rate.
} 


\section{International externalities}

As shown in the previous section, FX reserve requirements have the potential to reduce capital flows and hence be used as capital flow management measures. A substantial literature has highlighted that capital flow management measures may lead to capital flow deflection to similar or neighbouring economies (Forbes et al., 2016[32]; Giordani et al., 2017[33]; Pasricha et al., 2018[34]). Specifically, deflection has usually been identified in the following way: if country $A$ and $B$ are economically similar, the introduction of a control in country $A$ will reduce capital inflows from $C$ to $A$, and deflect capital flows towards country $B$ which has not introduced barriers. In this section, we seek to extend our baseline model to test for the potential of similar capital flow deflection dynamics following adjustments of $\mathrm{FX}$ reserve requirements.

We follow the empirical approach used in recent work on capital flow deflection by Gori et al $\left(2020_{[35]}\right)$ to test the existence of such international spillover. In particular, we add to our baseline regressions on capital flows a variable (the "spillover variable") which represent the sum of tightening actions in FX reserve requirements in similar economies.

Each FX RR adjustment is weighted by how similar a country is to the country adjusting RR and hence the most likely to receive more inflows. The choice of an adequate weighting scheme is not trivial: here countries' similarity is defined based on the correlation between capital inflows to both countries ${ }^{19}$. This implies the use of a continuous weighting scheme in which the set of weighs are defined by the timevarying bilateral correlation coefficient between the inflow of capital in the tightening country and another country. ${ }^{20}$ Specifically, the weights are computed on a rolling basis over the past 8 quarters capital inflows to both countries. The resulting spillover variable enters the regression with a lag. More details on the specification and construction of the spillover variable can be found in Gori et al. $\left(2020_{[35]}\right)$.

Results are displayed in Table A5. We start by testing potential spillovers effects of FX RR tightening on total inflows to GDP after one quarter (col 1-2) and do not find any effect for either the full country sample or an EME sample (capital flow deflection following capital controls has been mainly a feature of EMEs according to the recent literature). Neither do we find any spillover 2, 3 or 4 quarters after a RR tightening (col 4-6), or within a year time (col 7). Using fixed time correlations as weights rather than time-varying weights does not change the results ( $\mathrm{col} 3$ ). Changing the dependent variable to test for spillover effects on specific asset classes, we do not find evidence for any flow (FDI, equity, debt, credit) (col 8 to 11).

Overall, under this empirical specification, we don't find evidence of international spillovers in the form of capital flow deflection to similar economies after adjustments in FX RR, unlike traditional capital flow management tools. RR are targeted at domestic banks, which may be bearing the full costs of the measure rather than shifting it to international lenders/investors.

\footnotetext{
19 The economic rationale of this choice lies on the idea that, if capital inflows to two distinct countries co-move in relation to each other, this underlines similarity in the two countries' assets in the eyes of international investors. Gori et al $\left(2020_{[35]}\right)$ argue that this measure is more effective in measuring similarity among two countries than alternatives based on location (as assets even in nearby countries may have different investment characteristics) or fundamentals (as fundamentals are often unable to explain asset price dynamics).

${ }^{20}$ All negative inflow correlations to 0 . The idea is to eliminate from the set of similar countries, all economies whose capital inflow is negatively correlated with the one of the tightening countries, and whose policy shift would otherwise be added with negative sign (thus subtracted) from the spillover variable.
} 


\section{Robustness checks}

\section{Alternative method to control for endogeneity}

To test whether some of our baseline results may not be affected by simultaneity bias whereby it is not the policy change driving changes in the outcome variables, but the policy which actually replies to ongoing macroeconomic developments. Policy adjustments are likely endogenous to the variables they try to target. As shown in Rojas et al $\left(2020_{[36]}\right)$ for reserve requirements specifically, endogeneity concerns are real and may bias studies on their effectiveness. ${ }^{21}$ While our lag structure should mitigate the concern, it may not fully address it.

We closely follow the innovative technique used in Ahnert et al $\left(2018_{[5]}\right)$ in their study of currency-based measures. It seeks to estimate more "exogenous" policy shocks, thereby removing the potential for endogenous adjustments. The approach relies on a two-stage regression framework with a first stage estimating the likelihood of a policy change from a range of variables describing the macroeconomic and financial context of the country and likely to be followed by policymakers. It then regresses the baseline replacing the policy variables by the residuals obtained from the first stage (i.e. the variation of the policy changes that is not explained by macro-financial variables).

We regress both the change in the FX RR gap and the change in the average level of the RR on a range of variables which policymakers are likely to look at for deciding a policy change, namely: the lagged GDP growth to control for the business cycle, exchange rate change, bank credit growth for the credit cycles, various measures of inflows in the economy, and the main outcome variables of our baseline. This should control for the possible motivations for RRs: business cycle smoothing, exchange rate management, capital flow management, macroprudential intent. We also add the lagged level in the gap and lagged average RR to control for potential mean reverting dynamics (if the rate or gap is historically high, it is more likely to be brought down to "normal"). We also control for the contemporaneous change in interest rates by the central bank to control for interaction between the two tools in a monetary policy setting.

The two regressions for the first stage can be described as follows:

$$
\begin{aligned}
& \left(\Delta R R^{F}-\Delta R R^{L}\right)_{i t}=\alpha+\omega\left(R R^{F}-R R^{L}\right)_{i t-1}+\Gamma X_{i, t-1}+\delta_{i}+\delta_{T}+e_{i t} \\
& \Delta \text { average } R R_{i t}=\alpha+\mu \text { average } R R_{i t-1}+\partial X_{i, t-1}+\delta_{i}+\delta_{T}+e_{i t}
\end{aligned}
$$

Results for the gap are displayed in Table A6. While mean-reverting dynamics are confirmed (i.e. wider gap in the previous quarter reduces the chance of an increase), there does not appear to be any obvious driver of RR adjustments in our macro-financial variables. This is consistent with the nascent literature

\footnotetext{
${ }^{21}$ In a recent paper, Rojas et al (2020[36] $)$ use the narrative approach of Romer and Romer (2010) to identify exogenous reserve requirement changes based on press release and other reports of central banks introducing these changes. They achieve this for three countries and this method would not be suitable for the large number of countries that we have.
} 
explaining policy changes, which finds it hard to match real drivers and expected targets. While institutional and political variables are expected to play a non-negligible role in driving changes, e.g. central bank independence, they are irrelevant for the present exercise, which simply seeks to construct a measure of policy change that is exogenous to our outcome variables in the first place.

The absence of strong results for any macro-financial variables in our setting may in itself reduce reverse causality concerns, but we go ahead with a second stage for the variables we are concerned about: we select the model in col 2 as our baseline - in the absence of strong result for any specific variable, we prefer to select a model with the largest country sample.

We plug the residuals from this model back into our baseline model replacing our RR variables, keeping the specification with 4 lags of the policy variable:

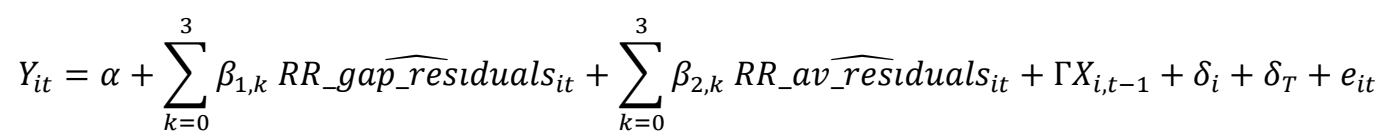

Tables A7 and A8 displays the results. We not only find that all of our previously significant results are confirmed in this model (a larger gap leading to lower FX liability share, and lower net FX positions, lower flows to non-banks and lower portfolio debt flows), but we also find the channel that was expected from our conceptual framework but turned out insignificant in our baseline specification: namely a higher RR gap leads to lower cross border flows to domestic banks.

All our previous results are also larger in terms of economic and statistical significance: the reduction in the net $\mathrm{FX}$ position is now2.3 percentage point. The reduction in portfolio debt inflows is also slightly higher at 0.29 . The reduction in the FX liability share is not only more important (close to 0.2 within a year) but also statistically stronger (just above the $1 \%$ threshold). ${ }^{22}$

We further find a positive and significant coefficient regarding the exchange rate deviation from a $3 Y$ trend. Instead of driving exchange rates towards undervaluation, this seems to have the opposite effect of strengthening the currency. We again note, however, that deviation from trend represent a crude proxy for exchange rate misalignment.

Overall, results from the "exogenous policy shock" model confirm our baseline findings while reducing reverse causality concerns and strengthen our conceptual channels.

\section{Does the effect of changes in reserve requirements depend on the initial level of the rate?}

The effect of a change in reserve requirements could well depend on the initial level of the reserve requirements. If it is already very high, a small change may not make a big difference, or on the other hand it could also be hypothesised because the reserve requirements is very tight, a small change would make a larger difference.

To test this, we rerun our baseline, this time scaling our variable of interest (the change in the FX RR gap) by the initial average level of reserve requirements (at time $\mathrm{t}-1$ ).

Formally, the new specification reads as follows:

\footnotetext{
${ }^{22}$ As robustness check, we also compute residuals from a first stage model that includes the lagged change in the $\mathrm{FX}$ liability share as an additional control (at the detriment of losing observations) and results from the second stage are almost identical.
} 


$$
Y_{i t}=\alpha+\sum_{k=0}^{3} \beta_{1, k}\left(\frac{\Delta R R_{-} G a p_{i, t-k}}{A v_{-} R R_{i, t-k-1}}\right)+\sum_{k=0}^{3} \beta_{2, k} \Delta \text { average } R R+\Gamma X_{i, t-1}+\delta_{i}+\delta_{T}+e_{i t}
$$

If $\beta_{1, k}$ displays higher statistical significance under this specification than under the baseline, we can conclude that the impact of changes in the FX RR gap on our specific outcome variable $Y_{i t}$ is non-linear and specifically, that the higher the initial average rate, the lower the impact of a change in the gap. We considered other empirical strategies, such as interacting with a dummy variable representing a high initial RR or a low one, similar to Alam et al (2019) study on LTV caps but such technic creates threshold effects around the decided cut-off. Interacting directly with the average RR level removes such issue but we find the inclusion of interaction terms to lead to the loss of too many degrees of freedom. Table A9 in the Annex displays the new results, comparing the coefficients from the baseline and the coefficients from Eq. 5.

Regarding direct effects, the coefficients are more significant for the FX liability share moving below the $5 \%$ threshold, which suggest some non-linearity there. The coefficient is a bit less significant in the case of the net FX position.

The difference is also striking regarding coefficients on indirect variables: the coefficient on capital flows to non-banks becomes substantially more significant, moving below the 0.01 threshold. Portfolio debt flows also becomes substantially more significant. Finally, the coefficient on the deviation from the $3 \mathrm{Y}$ trend becomes significant at the $5 \%$ level.

These results provide evidence of non-linearity with regards to the FX liability share, capital flows to nonbanks, portfolio debt flows and exchange rate deviation from the 3Y trend. Specifically, it supports the null hypothesis that the higher the initial average rate, the lower the impact of a change in the gap. It also provides reassurance that our baseline results are not significantly changed when controlling for potential non-linear effects.

\section{The value of intensity-based measures}

To illustrate the value of intensity based measures like ours compared to the easing/tightening binary variables used in the literature, we create binary $+1 /-1$ variables for our reserve requirements data (one for the rate on local currency liabilities, one for foreign currency, one for undifferentiated single reserve requirements) and run the same model to our continuous/intensity variables and our binary ones.

The baseline model used in the previous section used the concept of gap (differential between the FX-RR rate and the LC-RR rate). As binary variables do not capture information on the size of the change, they are mostly silent regarding an increase or decrease of the gap. In the spirit of comparability with previous models using binary variables used in the literature, we now estimate the following model: 


$$
\begin{gathered}
Y_{i t}=\alpha+\sum_{k=0}^{3} \beta_{L, k} \Delta R R_{i, t-k}^{L}+\sum_{k=0}^{3} \beta_{F, k} \Delta R R_{i, t-k}^{F}+\sum_{k=0}^{3} \beta_{S, k} \Delta R R_{i, t-k}^{S}+\sum_{k=0}^{3} \gamma_{R, k} R B M_{i, t-k} \\
+\sum_{k=0}^{3} \gamma_{C, k} C B M_{i, t-k}+\sum_{k=0}^{3} \gamma_{M, k} M P M_{i, t-k}+\Gamma X_{i, t-1}+\delta_{i}+\delta_{T}+e_{i t}
\end{gathered}
$$

We thus replace our variables of interest, replacing the gap between $\mathrm{FX}$ and LC rate by separate variables capturing change in the $\mathrm{FX}$ rate, change in the LC rate or change in the single reserve requirement rate in the case of undifferentiated reserve requirements.

We split the results between our "direct" outcome variables and our "indirect" outcome variables. Results are summarized in Table 3 and Table 4, with full results in Table A10 and Table A11.

First, we find that our previous results on the change in the gap and underlying channels are broadly confirmed when split between the rate on FX liabilities, the rate on local currency-denominated liabilities, and the rate on single reserve requirements. An increase in FX reserve requirement ratios is in itself associated a reduction in the net FX position and a reduction in portfolio debt flows. An increase in the rate on LC liabilities largely produce a symmetrically opposite effect, namely an increase in the net FX position, an increase in flows to non-banks, and an increase in portfolio equity and debt flows, which provides some reassurance on the significance of our results using the gap.

Second, the comparison between the results using a binary policy indicator vs. our intensity based measure of reserve requirements rate strongly highlights the need to consider the intensity of measures. There appear to be very significant differences between the two policy indicators. The main difference lies in the significance of the results, e.g. a binary indicator does not pick up a statistically significant reduction in the net FX position, from an increase in FX RR rates (or decrease in LC rate). Reversely, there are also cases where a binary indicator may wrongly pick up a statistically significant effect. Notably, the results of an decrease in the RR ratio on LC liabilities on the higher issuance of NFC debt abroad highlighted in Ahnert et al. $\left(2018_{[5]}\right)$ is found significant using a binary policy variable but not using intensity-based measures.

Table 3 - The direct effect of reserve requirements: intensity-based measures vs. easing/tightening

\begin{tabular}{|c|c|c|c|c|c|c|c|c|}
\hline & \multicolumn{2}{|c|}{ Inflows to banks } & \multicolumn{2}{|c|}{$\Delta F X$ loans share } & \multicolumn{2}{|c|}{$\Delta \mathrm{FX}$ liab share } & \multicolumn{2}{|c|}{$\Delta$ Net FX position } \\
\hline & rates & binary & rates & binary & rates & binary & rates & binary \\
\hline$\Delta \mathrm{FX} R \mathrm{R}$ rate $(\mathrm{t}, \mathrm{t}-4)$ & -0.078 & -0.187 & -0.065 & 0.146 & -0.032 & $0.515^{\star *}$ & $-1.594^{* * *}$ & -2.068 \\
\hline$\Delta \mathrm{LC}$ RR rate $(\mathrm{t}, \mathrm{t}-4)$ & 0.128 & 0.526 & 0.181 & $0.997^{*}$ & 0.235 & $0.629 * * *$ & $0.831^{* *}$ & 1.16 \\
\hline$\Delta$ single $R R$ rate $(t, t-4)$ & 0.198 & 0.267 & 1.637 & 6.736 & 0.153 & 1.116 & 0.847 & 2.58 \\
\hline $\mathbf{N}$ & 2,773 & 2,773 & 891 & 891 & 1,029 & 1,029 & 797 & 797 \\
\hline Countries & 49 & 49 & 25 & 25 & 29 & 29 & 35 & 35 \\
\hline
\end{tabular}
binary variables

Note: ${ }^{*} p<0.10,{ }^{* *} p<0.05,{ }^{* * *} p<0.01$ 
Table 4 - The indirect effect of reserve requirements: intensity-based measures vs. easing/tightening binary variables

\begin{tabular}{|c|c|c|c|c|c|c|c|c|}
\hline & \multicolumn{2}{|c|}{ NFC debt growth } & \multicolumn{2}{|c|}{$\begin{array}{l}\text { Inflows to non- } \\
\text { banks }\end{array}$} & \multicolumn{2}{|c|}{ Equity Inflows } & \multicolumn{2}{|c|}{ Debt Inflows } \\
\hline & rates & binary & rates & binary & rates & binary & rates & binary \\
\hline$\Delta F X R R$ rate $(t, t-4)$ & 0.00 & 0.09 & -0.06 & -0.15 & -0.021 & -0.086 & $-0.169^{* *}$ & -0.631 \\
\hline$\Delta \mathrm{LC} \mathrm{RR}$ rate $(\mathrm{t}, \mathrm{t}-\mathrm{4})$ & -0.01 & $-0.07^{* * *}$ & $0.121^{\text {*** }}$ & $0.399^{* *}$ & $0.055^{*}$ & 0.20 & $0.369^{* * *}$ & $1.045^{* *}$ \\
\hline$\Delta$ single $R R$ rate $(t, t-4)$ & 0.01 & $0.03^{* *}$ & -0.03 & -0.17 & -0.04 & 0.03 & -0.06 & -0.22 \\
\hline $\mathrm{N}$ & 2,826 & 2,826 & 2,773 & 2,773 & 2,702 & 2,702 & 2,703 & 2,703 \\
\hline Countries & 51 & 51 & 49 & 49 & 48 & 48 & 48 & 48 \\
\hline
\end{tabular}

\begin{tabular}{lcccccc}
\hline & \multicolumn{2}{c}{ Other Inflows } & \multicolumn{2}{c}{ Exchange rate } & \multicolumn{2}{c}{ Exchange rate } \\
\hline & rates & binary & rates & binary & rates & binary \\
$\Delta$ FX RR rate $(\mathrm{t}, \mathrm{t}-4)$ & -0.153 & -0.228 & 0.472 & $15.153^{*}$ & -1.656 & -5.754 \\
$\Delta$ LC RR rate $(\mathrm{t}, \mathrm{t}-4)$ & 0.09 & 0.34 & -1.22 & 3.68 & 0.94 & 5.20 \\
$\Delta$ single RR rate $(\mathrm{t}, \mathrm{t}-4)$ & 0.10 & -0.19 & -0.43 & -1.13 & -0.05 & -0.03 \\
$\mathrm{~N}$ & 2,763 & 2,763 & 2,545 & 2,545 & 2,196 & 2,196 \\
Countries & 49 & 49 & 48 & 48 & 48 & 48 \\
\hline
\end{tabular}

Note: ${ }^{*} p<0.10,{ }^{* *} p<0.05,{ }^{* * *} p<0.01$

\section{Policy implications and possible areas of future work}

This study offers a detailed assessment of the impact of currency-differentiated reserve requirements: it provides new evidence for policy-makers regarding the benefits and externalities of such a tool, by quantifying the impact of an increase in the gap between FX and local currency reserve requirements on key target variables.

From a policy perspective, the paper points to their usefulness in reducing dollarization and currency mismatches in the banking sector without an obvious shifting of risk to other sectors or other countries. However, policymakers should be mindful of the effects that such measures may have on capital flows more broadly. While currency-differentiated reserve requirements may be effective macroprudential tools, in certain cases they may share the features of capital flow management measures.

From an empirical perspective, this paper shows the limitations of using binary variables when conducting analytical studies on the effectiveness of macro-prudential tools. Therefore, where possible, policy makers are advised to test the effectiveness of their tools capturing the intensity of the measure. When using binary variables, researches should be mindful of the limitations that such quantitative studies may have. As experience grows, it is advisable to study in details other macro-prudential tools with intensity-based measures. 
Finally, further work should be done on precisely identifying the transmission channels. Work using banks' balance sheet data could be a welcome avenue for future research, which would enable both a closer identification of transmission channels as well as heterogeneous effect of reserve requirements across different types of banks, likely hidden in the country-level data that this paper has been using.

\section{References}

Agénor, P., K. Alper and L. Pereira da Silva (2018), "External shocks, financial volatility and reserve requirements in an open economy", Journal of International Money and Finance, Vol. 83, pp. 23-43, http://dx.doi.org/10.1016/J.JIMONFIN.2018.01.003.

Ahnert, T. et al. (2018), Macroprudential FX Regulations: Shifting the Snowbanks of FX Vulnerability?, National Bureau of Economic Research, Cambridge, MA, http://dx.doi.org/10.3386/w25083.

Aiyar, S., C. Calomiris and T. Wieladek (2012), "Does Macro-Pru Leak? Evidence from a UK Policy Experiment", NBER Working Papers, https://ideas.repec.org/p/nbr/nberwo/17822.html (accessed on 7 August 2019).

Akinci, O. and J. Olmstead-Rumsey (2018), "How effective are macroprudential policies? An empirical investigation", Journal of Financial Intermediation, Vol. 33, pp. 33-57, http://dx.doi.org/10.1016/J.JFI.2017.04.001.

Alam, Z. et al. (2019), "Digging Deeper--Evidence on the Effects of Macroprudential Policies from a New Database", IMF Working Papers, No. 19/66, https://www.imf.org/en/Publications/WP/Issues/2019/03/22/Digging-Deeper-Evidence-on-theEffects-of-Macroprudential-Policies-from-a-New-Database-46658 (accessed on 26 April 2019).

Armas, A., P. Castillo and M. Vega (2014), Inflation Targeting and Quantitative Tightening: Effects of Reserve Requirements in Peru, http://www.iadb.org.

Blundell, R. and S. Bond (2000), "GMM Estimation with persistent panel data: An application to production functions", Econometric Reviews, Vol. 19/3, pp. 321-340, http://dx.doi.org/10.1080/07474930008800475.

Brei, M. and R. Moreno (2018), "Reserve requirements and capital flows in Latin America", BIS Working Papers, http://www.bis.org.

Bruno, V., I. Shim and H. Shin (2017), "Comparative assessment of macroprudential policies", Journal of Financial Stability, Vol. 28, pp. 183-202, http://dx.doi.org/10.1016/J.JFS.2016.04.001.

Camors, C., J. Peydró and F. Rodriguez-Tous (2019), "Macroprudential and monetary policy: Loan-level evidence from reserve requirements", Economics Working Papers. 
Cantú, C. et al. (2019), "Reserve requirements as a financial stability instrument", BCRP Working Paper.

Carstens, A. (2019), "Exchange rates and monetary policy frameworks in emerging market economies", https://www.bis.org/speeches/sp190502.htm (accessed on 4 July 2019).

Cerutti, E. et al. (2017), "Changes in Prudential Policy Instruments-A New Cross-Country Database", International Journal of Central Banking, http://www.newyorkfed.org/IBRN/index.html. (accessed on 15 January 2019).

Chui, M., E. Kuruc and P. Turner (2016), "A new dimension to currency mismatches in the emerging markets - non-financial companies", BIS Working Papers, http://www.bis.org (accessed on 20 June 2019).

de Crescenzio, A., M. Golin and F. Molteni (2017), "Have currency-based capital flow management measures curbed international banking flows?", OECD Working Papers on International Investment, No. 2017/4, OECD Publishing, Paris, https://dx.doi.org/10.1787/c0cc3f28-en.

de Crescenzio, A., M. Golin and A. Ott (2015), "Currency-based measures targeting banks Balancing national regulation of risk and financial openness", OECD Working Papers on International Investment, No. 2015/3, OECD Publishing, Paris, https://dx.doi.org/10.1787/5jrp0z9lp1zr-en.

Eller, M. et al. (2020), "Macroprudential policies in CESEE-an intensity-adjusted approach", Focus on European Economic Integration.

Federico, P., C. Vegh and G. Vuletin (2014), Reserve Requirement Policy over the Business Cycle, National Bureau of Economic Research, Cambridge, MA, http://dx.doi.org/10.3386/w20612.

Fendoğlu, S. (2017), "Credit cycles and capital flows: Effectiveness of the macroprudential policy framework in emerging market economies", Journal of Banking \& Finance, Vol. 79, pp. 110128, http://dx.doi.org/10.1016/J.JBANKFIN.2017.03.008.

Fendoğlu, S. (2017), "Credit cycles and capital flows: Effectiveness of the macroprudential policy framework in emerging market economies", Journal of Banking \& Finance, Vol. 79, pp. 110128, http://dx.doi.org/10.1016/J.JBANKFIN.2017.03.008.

Forbes, K. et al. (2016), "Bubble thy neighbour: Portfolio effects and externalities from capital controls", Journal of International Economics, Vol. 99, pp. 85-104, http://dx.doi.org/10.1016/J.JINTECO.2015.12.010.

Frost, J., H. Ito and R. Van Stralen (2020), The effectiveness of macroprudential policies and capital controls against volatile capital inflows, http://www.bis.org.

Giordani, P. et al. (2017), "Capital flow deflection”, Journal of International Economics, Vol. 105, pp. 102-118, http://dx.doi.org/10.1016/j.jinteco.2016.12.007.

Glocker, C. and P. Towbin (2012), "Reserve Requirements for Price and Financial Stability: When Are They Effective? *", International Journal of Central Banking. 
Glocker, C. and P. Towbin (2012), "The Macroeconomic Effects of Reserve Requirements The Macroeconomic Effects of Reserve Requirements THE MACROECONOMIC EFFECTS OF RESERVE REQUIREMENTS", WIFO Working Papers, http://www.wifo.ac.at/wwa/pubid/43532.

Gori, F., E. Lepers and C. Mehigan (2020), "Capital flow deflection under the magnifying glass", OECD Economics Department Working Papers, No. 1613, OECD Publishing, Paris, https://dx.doi.org/10.1787/398180d0-en.

Gori, F., E. Lepers and C. Mehigan (2020), "Capital Flow Deflection under the Magnifying Glass", mimeo.

Gray, S. (2011), "Central Bank Balances and Reserve Requirements”, IMF Working Paper.

Jordà, Ò. and A. Taylor (2016), "The Time for Austerity: Estimating the Average Treatment Effect of Fiscal Policy", The Economic Journal, Vol. 126/590, pp. 219-255, http://dx.doi.org/10.1111/ecoj.12332.

Kuttner, K. and I. Shim (2016), "Can non-interest rate policies stabilize housing markets? Evidence from a panel of 57 economies", Journal of Financial Stability, Vol. 26, pp. 31-44, http://dx.doi.org/10.1016/j.jfs.2016.07.014.

Landau, J. (2018), "A Liquidity-Based Approach to Macroprudential Policy", in Macroprudential Policy and Practice, Cambridge University Press, http://dx.doi.org/10.1017/9781108304429.003.

Lepers, E. and C. Mehigan (2019), "The broad policy toolkit for financial stability: Foundations, fences, and fire doors", OECD Working Papers on International Investment, No. 2019/02, OECD Publishing, Paris, https://dx.doi.org/10.1787/9188f06a-en.

Lepers, E. and R. Mercado (2020), "Sectoral Capital Flows: Covariates, Comovements, and Controls”, SEACEN Working Paper.

Lim, C. et al. (2011), "Macroprudential Policy: What Instruments and How to Use Them? Lessons from Country Experiences IMF Working Paper Monetary and Capital Markets Department Macroprudential Policy: What Instruments and How to Use Them? Lessons from Country Experiences 1", IMF Working Paper.

Loeffler, A. (2015), "Reserve Requirements and Real Exchange Rate Misalignments in Emerging Market Economies", Review of Development Economics, http://dx.doi.org/10.1111/rode.12164.

McKinnon, R. (1973), Money and capital in economic development, Brookings Institution.

Mimir, Y. and E. Sunel (2019), "External Shocks, Banks, and Optimal Monetary Policy: A Recipe for Emerging Market Central Banks", International Journal of Central Banking, http://www.yasinmimir.com.

Mimir, Y., E. Sunel and T. Taşkin (2013), "Required reserves as a credit policy tool", B.E. Journal of Macroeconomics, Vol. 13/1, pp. 823-880, http://dx.doi.org/10.1515/bejm-2012-0093.

Montoro, C. and R. Moreno (2011), "The use of reserve requirements as a policy instrument in Latin America", BIS Quarterly Review, https://www.bis.org/publ/qtrpdf/r gt1103g.htm (accessed on 27 June 2019). 
OECD (2020), COVID-19 and Global Capital Flows.

OECD (2019), Reserve Requirements: Current Use, Motivations and Practical Considerations.

Özsöz, E., E. Rengifo and A. Kutan (2015), "FOREIGN CURRENCY LENDING AND BANKING SYSTEM STABILITY: NEW EVIDENCE FROM TURKEY", Central Bank Review, Vol. 15, pp. 1-29.

Pasricha, G. et al. (2018), "Domestic and multilateral effects of capital controls in emerging markets", Journal of International Economics, Vol. 115, pp. 48-58, http://dx.doi.org/10.1016/J.JINTECO.2018.08.005.

Richter, B., M. Schularick and I. Shim (2019), "The costs of macroprudential policy", Journal of International Economics, http://dx.doi.org/10.1016/J.JINTECO.2018.11.011.

Robitaille, P. (2011), "Liquidity and Reserve Requirements in Brazil", Board of Governors of the Federal Reserve System Working Papers, http://www.ssrn.com.

Rojas, D., C. Vegh and G. Vuletin (2020), "The Macroeconomic Effects of Macroprudential Policy: Evidence from a Narrative Approach", NBER Working Papers, http://www.nber.org/papers/w27687.

Roodman, D. (2009), How to do xtabond2: An introduction to difference and system GMM in Stata.

Schularick, M. and I. Shim (2017), "Household credit in Asia-Pacific”, BIS Papers 91.

Terrier, G. et al. (2011), "Policy Instruments To Lean Against The Wind In Latin America", IMF Working Paper Series.

Tovar, C., M. Garcia-Escribano and M. Vera Martin (2012), "Credit Growth and the Effectiveness of Reserve Requirements and Other Macroprudential Instruments in Latin America", IMF Working Paper.

Vandenbussche, J., U. Vogel and E. Detragiache (2015), "Macroprudential Policies and Housing Prices: A New Database and Empirical Evidence for Central, Eastern, and Southeastern Europe", Journal of Money, Credit and Banking, Vol. 47/S1, pp. 343-377, http://dx.doi.org/10.1111/jmcb.12206.

Vargas, H. et al. (2010), "Effects of Reserve Requirements in an Inflation Targeting Regime: The Case ofColombia", Borradoras de Economia, Central Bank of Colombia, http://www.banrep.gov.co/sites/default/files/publicaciones/archivos/borra587.pdf (accessed on 1 August 2019).

Yılmaz, F. (2020), "How Do Credits Dollarize? The Role of Firm's Natural Hedges, Banks' Core and Non-Core Liabilities", Central Bank of Turkey Working Paper. 
Annex A. Supplementary materials 
Figure A 1: Adjustments in single reserve requirements

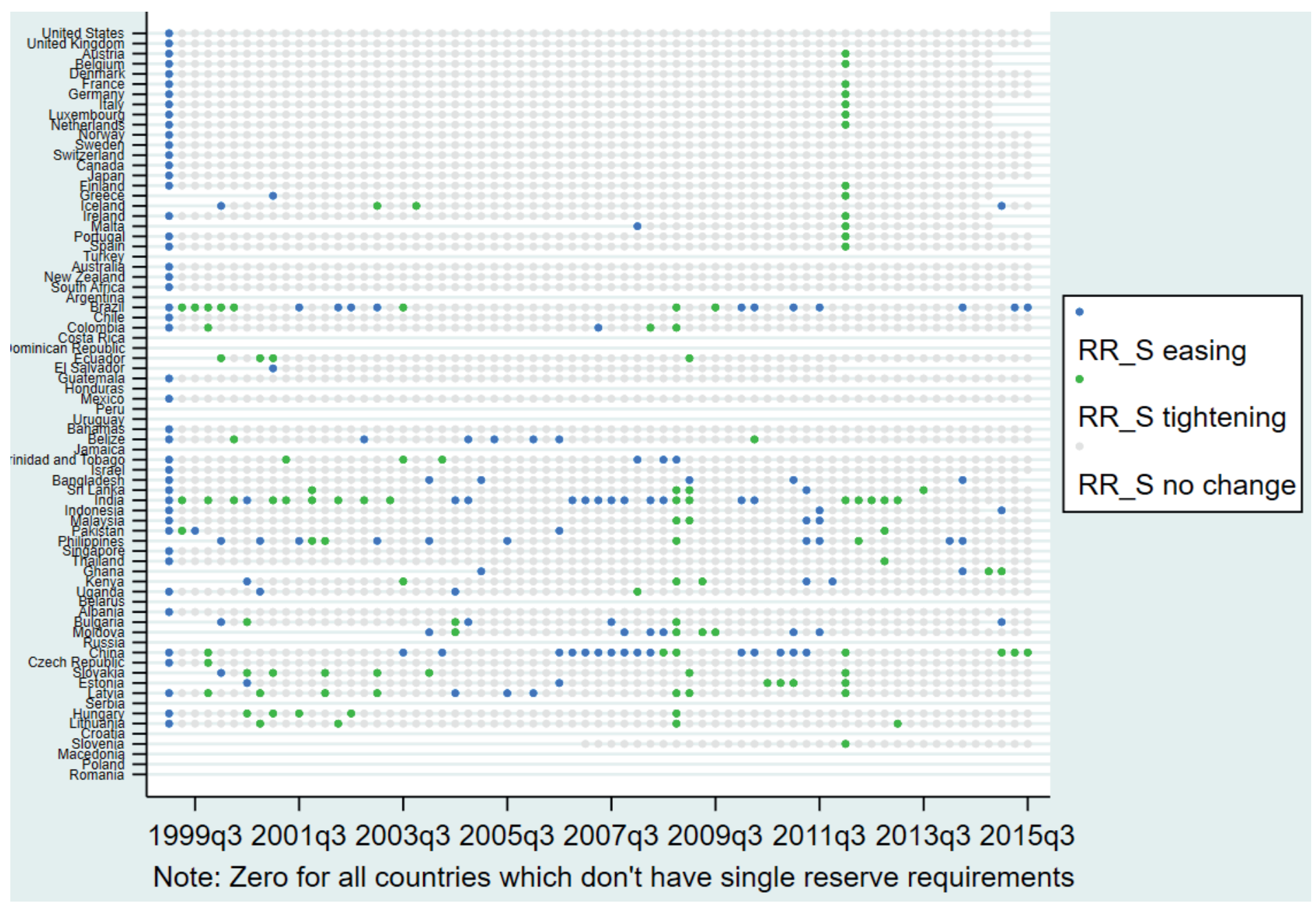

ASSESSING THE EFFECTIVENESS OF CURRENCY-DIFFERENTIATED TOOLS @ OECD 2021 
Figure A 2 - Adjustments in reserve requirements on FX liabilities

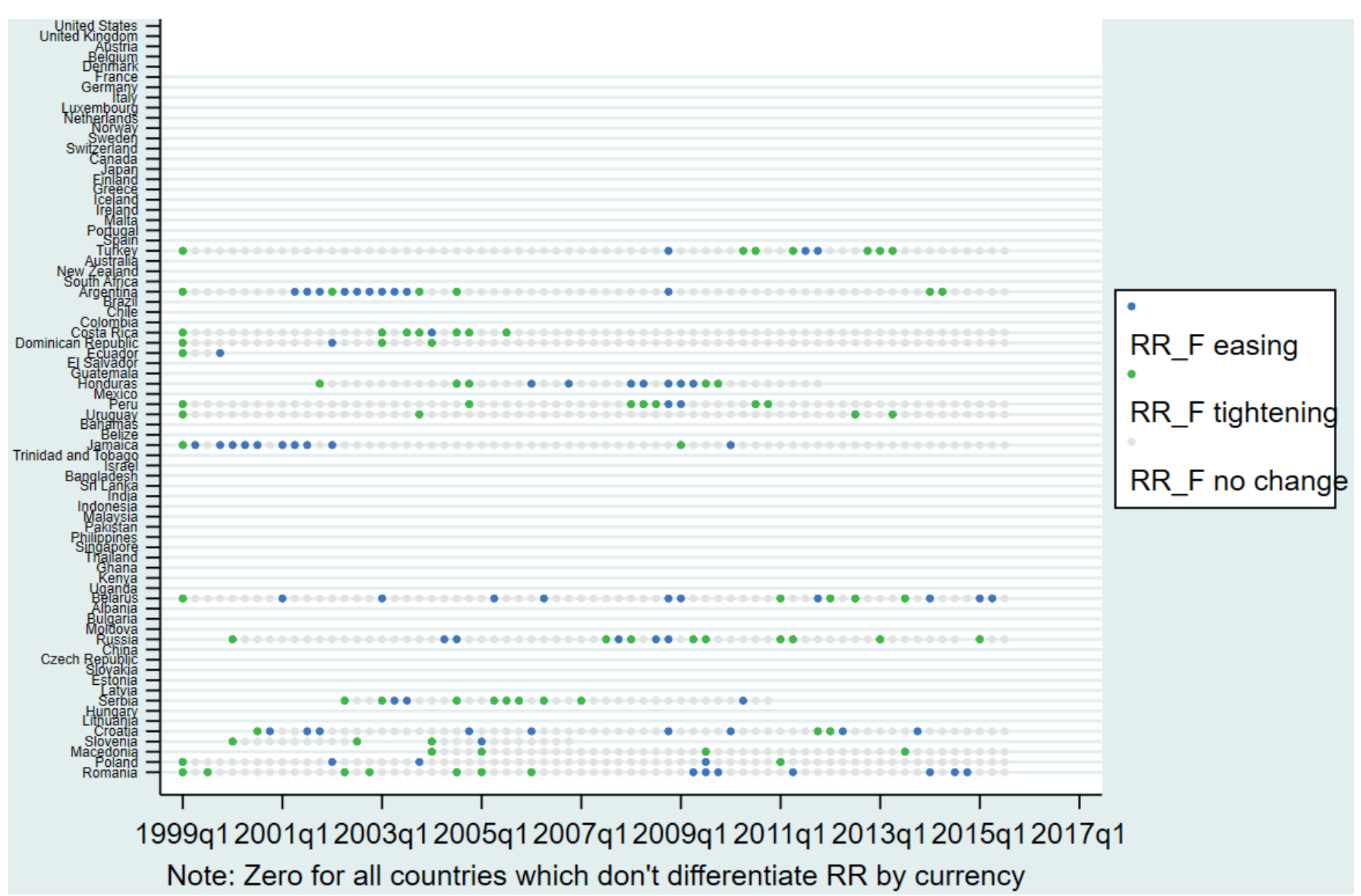




\section{Table A 1: Variable descriptions}

\begin{tabular}{|c|c|c|}
\hline Indicators & Description & Data source \\
\hline Reserve requirements & $\begin{array}{l}\text { Average of the rates for reserve requirements on } \\
\text { local currency liabilities and on foreign currency } \\
\text { liabilities. } \\
\text { The differential is computed as the difference } \\
\text { between the FX and the LC rate. }\end{array}$ & $\begin{array}{l}\text { Fernandez et al (2015), } \\
\text { OECD (2019), authors' } \\
\text { collection for individual } \\
\text { countries }\end{array}$ \\
\hline $\begin{array}{lr}\begin{array}{l}\text { Financial } \\
\text { adjustments }\end{array} & \begin{array}{r}\text { policy } \\
\text { (Currency }\end{array} \\
\text { based } & \text { measures, } \\
\text { residency } & \text { based } \\
\text { measures, } & \text { and } \\
\text { macroprudential } & \\
\text { measures } & \\
\end{array}$ & $\begin{array}{l}\text { Easing adjustment or removal of the measure is } \\
\text { coded as }-1 \text { and introduction or tightening } \\
\text { adjustment is coded as }+1 \text {. } \\
\text { Description of the policies included under the broad } \\
\text { policy types is described in Lepers and Mehigan } \\
\text { (2019) }\end{array}$ & $\begin{array}{l}\text { Lepers and Mehigan } \\
\text { (2019) based on de } \\
\text { Crescenzio et al. (2017) } \\
\text { and Alam et al. (2019) }\end{array}$ \\
\hline $\begin{array}{ll}\text { Exchange } & \text { rate } \\
\text { appreciation } & \end{array}$ & $\begin{array}{l}\text { Computed year on year. Real effective exchange } \\
\text { rate. }\end{array}$ & BIS Exchange rate data. \\
\hline $\begin{array}{l}\text { Exchange rate deviation } \\
\text { from trend }\end{array}$ & $\begin{array}{l}\text { Computed as the deviation from } 3 \text { or } 5 \text { year trends } \\
\text { ( } 12 \text { or } 20 \text { quarters). }\end{array}$ & BIS \\
\hline Domestic Interest Rate & & IMF IFS, BIS \\
\hline NFC debt growth & $\begin{array}{l}\text { International debt issuance by domestic NFC. Year } \\
\text { on year growth. }\end{array}$ & $\mathrm{BIS}$ \\
\hline $\begin{array}{l}\text { Share of FX loans to } \\
\text { total loans }\end{array}$ & & $\begin{array}{l}\text { IMF IFS, ECB SDW, } \\
\text { national central banks, } \\
\text { bilateral exchanges }{ }^{1}\end{array}$ \\
\hline $\begin{array}{l}\text { Share of FX liabilities to } \\
\text { total liabilities }\end{array}$ & & $\begin{array}{l}\text { IMF IFS, ECB SDW, } \\
\text { national central banks, } \\
\text { bilateral exchanges }\end{array}$ \\
\hline GDP growth & & IMF IFS, OECD \\
\hline $\begin{array}{l}\text { Net open position in } \\
\text { foreign exchange to } \\
\text { capital }\end{array}$ & & IMF FSI \\
\hline Sovereign ratings & Foreign currency long term sovereign ratings & Fitch \\
\hline Capital flows & $\begin{array}{l}\text { Portfolio debt, portfolio equity, other flows, FDI } \\
\text { flows. Net incurrence of liabilities to non-residents. } \\
\text { All our flow variables are divided by annual GDP as } \\
\text { we interpret the effectiveness of RR changes over } 4 \\
\text { quarters but we calculate a } 4 \text { quarters moving } \\
\text { average of annual GDP to avoid sharp changes from } \\
\text { Q4 to Q1 }\end{array}$ & IMF BoP \\
\hline Inflows to banks & $\begin{array}{l}\text { Claims from BIS reporting banks to bank sector in } \\
\text { the counterpart countries. FX/break adjusted } \\
\text { change. }\end{array}$ & BIS LBS ${ }^{2}$ \\
\hline Inflows to non-banks & $\begin{array}{l}\text { Claims from BIS reporting banks to non-bank sector } \\
\text { in the counterpart countries. FX/break adjusted } \\
\text { change. }\end{array}$ & BIS LBS \\
\hline
\end{tabular}


1. The BIS locational banking statistics does not allow us to have a complete picture of the share of FX assets and liabilities as countries have been reporting reporting banks' local currency liabilities to residents only since 2012Q2. Before only the cross-border position was reported.

2. We use the perspective of the counterpart countries, which provides us data on sectoral breakdown: it represents claims from BIS reporting banks to specific sectors in the counterpart countries. We get the cross-border flows to the bank and non-bank sector of the counterpart country. For this we do not have the currency breakdown, however it allows to increase the size of the country sample substantially. As we are interested in the change/flow rather than the stocks, we take the FX/break adjusted change calculated by the BIS which is better than a change in stocks that do not capture exchange rate developments.

Table A 2 - Summary Statistics

\begin{tabular}{lccccc}
\multicolumn{1}{c}{ Variable } & Obs & Mean & Std. Dev. & Min & Max \\
\hline & & & & & \\
Gap ( $\Delta$ RR_F- $\Delta$ RR_L) & 4,611 & 0.0178428 & 1.059108 & -26.5 & 18.34667 \\
$\Delta$ average RR & 4,611 & -0.0166276 & 1.0795 & -20.5 & 26.66667 \\
& & & & & \\
Bank credit growth & 2,490 & 0.0150281 & 0.056374 & -0.1153025 & 0.1440322 \\
Non-bank credit growth & 2,486 & 0.0143449 & 0.072938 & -0.155385 & 0.2159394 \\
Growth of NFC international debt & 3,414 & 0.0309675 & 0.1035836 & -0.1416452 & 0.4869565 \\
Share of FX loans & 1,093 & 24.53647 & 18.61165 & 0.4874488 & 74.05593 \\
Share of FX liabilities & 1,191 & 28.61181 & 19.21889 & 0.4935407 & 79.64165 \\
Debt flows to GDP & 2,984 & 0.7807501 & 2.083191 & -4.121718 & 9.228422 \\
Other flows to GDP & 3,052 & 1.181445 & 4.486062 & -8.406113 & 20.01204 \\
Equity flows to GDP & 2,987 & 0.7007535 & 2.978283 & -0.9386653 & 18.54914 \\
Inflows to banks (FX) & 1,950 & 0.589097 & 4.295238 & -12.43404 & 16.21212 \\
Inflows to banks (LC) & 1,613 & 0.3245244 & 3.925478 & -12.05668 & 17.87613 \\
$\Delta$ total FX liabilities & 1,872 & 1.022548 & 5.541807 & -13.2146 & 22.37378 \\
Inflows to non banks & 3,468 & 0.2997972 & 1.322873 & -2.813571 & 5.729673 \\
Inflows to banks & 3,468 & 0.4892331 & 3.277053 & -8.784652 & 12.8278 \\
Net FX position (\% capital) & 1,496 & 2.501967 & 16.33829 & -53.41409 & 59.88136 \\
\hline
\end{tabular}


Table A 3 - Direct effect of changes in reserve requirements

\begin{tabular}{|c|c|c|c|c|}
\hline Dependent variable & (1) & (2) & $\begin{array}{c}\text { (3) } \\
\text { FX }\end{array}$ & $\begin{array}{c}(4) \\
4 \text { Net FX }\end{array}$ \\
\hline Dependent varlable & CB_toDanks_Flows & $\Delta r X \_$loans_snare & $\Delta \vdash x \_$llab_snare & $\Delta$ Net_rX_pos_FSI \\
\hline \multirow[t]{2}{*}{ Gap ( $\Delta$ RR_F- $\left.\Delta R R \_L\right)$} & -0.020 & -0.060 & -0.000 & $-1.221^{\star * *}$ \\
\hline & 0.320 & 0.547 & 0.996 & 0.002 \\
\hline \multirow[t]{2}{*}{$\operatorname{Gap}\left(\Delta R R \_F-\Delta R R \_L\right)(t-1)$} & -0.034 & -0.042 & -0.060 & 0.271 \\
\hline & 0.294 & 0.602 & 0.191 & 0.107 \\
\hline \multirow[t]{2}{*}{ Gap ( $\left.\Delta R R \_F-\Delta R R \_L\right)(t-2)$} & -0.019 & -0.072 & -0.038 & -0.340 \\
\hline & 0.524 & 0.366 & 0.432 & 0.223 \\
\hline \multirow[t]{2}{*}{$\operatorname{Gap}\left(\Delta R R \_F-\Delta R R \_L\right)(t-3)$} & -0.031 & -0.052 & -0.013 & $-0.330^{*}$ \\
\hline & 0.419 & 0.292 & 0.553 & 0.075 \\
\hline sum coef $[t ; t-3]$ & -0.104 & -0.226 & $-0.111^{*}$ & $-1.62^{* * *}$ \\
\hline$p$ value of sum test & 0.319 & 0.443 & 0.083 & 0.008 \\
\hline \multirow[t]{2}{*}{$\Delta$ average $R R$} & 0.022 & 0.224 & 0.021 & -0.154 \\
\hline & 0.303 & 0.476 & 0.497 & 0.212 \\
\hline \multirow[t]{2}{*}{$\Delta$ average $\mathrm{RR}(\mathrm{t}-1)$} & 0.038 & 0.122 & 0.104 & -0.087 \\
\hline & 0.219 & 0.420 & 0.121 & 0.561 \\
\hline \multirow[t]{2}{*}{$\Delta$ average RR (t-2) } & -0.019 & 0.130 & 0.017 & 0.383 \\
\hline & 0.597 & 0.332 & 0.471 & 0.330 \\
\hline \multirow[t]{2}{*}{$\Delta$ average $R R(t-3)$} & 0.002 & -0.017 & -0.024 & 0.103 \\
\hline & 0.959 & 0.665 & 0.353 & 0.565 \\
\hline \multirow[t]{2}{*}{ CBM } & 1.957 & -0.250 & -0.151 & 0.757 \\
\hline & 0.356 & 0.916 & 0.914 & 0.857 \\
\hline \multirow[t]{2}{*}{ CBM (t-1) } & 1.303 & -3.726 & $-4.918^{\star \star \star}$ & -1.136 \\
\hline & 0.473 & 0.106 & 0.007 & 0.759 \\
\hline \multirow[t]{2}{*}{ CBM (t-2) } & -0.846 & -3.405 & -0.047 & 0.842 \\
\hline & 0.594 & 0.147 & 0.980 & 0.850 \\
\hline \multirow[t]{2}{*}{ CBM (t-3) } & 0.455 & -1.568 & $-1.761^{*}$ & 1.907 \\
\hline & 0.735 & 0.239 & 0.053 & 0.587 \\
\hline \multirow[t]{2}{*}{ RBM_inf } & -0.514 & -1.284 & -0.298 & 0.665 \\
\hline & 0.317 & 0.175 & 0.561 & 0.435 \\
\hline \multirow[t]{2}{*}{ RBM_inf(t-1) } & -0.965 & -0.970 & 0.452 & 1.555 \\
\hline & 0.246 & 0.244 & 0.365 & 0.344 \\
\hline \multirow[t]{2}{*}{ RBM_inf(t-2) } & -0.176 & -0.485 & 0.084 & 0.378 \\
\hline & 0.704 & 0.523 & 0.802 & 0.611 \\
\hline \multirow[t]{2}{*}{ RBM_inf(t-3) } & -0.916 & -0.343 & 0.433 & -0.366 \\
\hline & 0.257 & 0.227 & 0.411 & 0.522 \\
\hline MPM & $4.024^{* *}$ & 2.238 & 0.291 & 3.384 \\
\hline & 0.017 & 0.128 & 0.802 & 0.471 \\
\hline MPM (t-1) & 2.704 & 1.474 & -3.403 & $9.784^{*}$ \\
\hline & 0.404 & 0.304 & 0.121 & 0.055 \\
\hline MPM (t-2) & 4.331 & 2.081 & $3.766^{* * *}$ & 2.384 \\
\hline & 0.102 & 0.192 & 0.003 & 0.680 \\
\hline MPM (t-3) & 2.603 & -1.196 & 0.543 & -2.597 \\
\hline & 0.294 & 0.372 & 0.770 & 0.619 \\
\hline GDP growth ( $(-1)$ & $0.069^{\star \star *}$ & -0.040 & $-0.050^{*}$ & -0.008 \\
\hline & 0.004 & 0.329 & 0.052 & 0.935 \\
\hline Int. rate $(t-1)$ & & -0.009 & -0.004 & 0.091 \\
\hline & & 0.851 & 0.904 & 0.408 \\
\hline Exchange rate growth ( $t-1)$ & 1.354 & $2.758^{* *}$ & 0.912 & 0.255 \\
\hline & 0.362 & 0.024 & 0.120 & 0.881 \\
\hline Int rate differential (t-1) & -0.025 & & & \\
\hline & 0.166 & & & \\
\hline Sovereign rating $(t-1)$ & $0.244^{\star * *}$ & & & \\
\hline & 0.009 & & & \\
\hline Constant & $-4.700^{\star *}$ & 0.562 & 0.509 & $-1.663^{\star \star \star}$ \\
\hline & 0.026 & 0.447 & 0.331 & 0.002 \\
\hline Country FE & $\bar{Y}$ & $\mathrm{Y}$ & $\mathrm{Y}$ & $\bar{Y}$ \\
\hline Year FE & Y & Y & Y & Y \\
\hline Observations & 2,773 & 891 & 1,029 & 797 \\
\hline R-squared & 0.117 & 0.042 & 0.054 & 0.052 \\
\hline Number of ifs code & 49 & 25 & 29 & 35 \\
\hline
\end{tabular}

Note: ${ }^{*} p<0.10,{ }^{* *} p<0.05,{ }^{* * *} p<0.01$. Standard errors clustered at country level. Italic text displays the sum of the coefficients for all four lags, and the $p$-value of the sum test is displayed below rather that the standard errors as for the other coefficients in this table. 
Table A 4 - Indirect effect of changes in reserve requirements

\begin{tabular}{|c|c|c|c|c|c|c|c|}
\hline & $\begin{array}{c}\text { (1) } \\
\text { NFC debt growth } \\
\end{array}$ & $\begin{array}{c}(2) \\
\text { CB_tononbanks_Flows }\end{array}$ & $\begin{array}{c}(3) \\
\text { equity flow }\end{array}$ & $\begin{array}{c}(4) \\
\text { portfolio debt flow } \\
\end{array}$ & $\begin{array}{c}5) \\
\text { creditfllow } \\
\end{array}$ & $\begin{array}{c}6) \\
\text { ER dev } 3 Y \\
\end{array}$ & $\begin{array}{c}(7) \\
\text { ER dev } 5 Y \\
\end{array}$ \\
\hline \multirow[t]{2}{*}{ Gap ( $\left.\Delta R R \_F-\Delta R R \_L\right)$} & 0.000 & -0.005 & $-0.012^{*}$ & -0.025 & 0.004 & -0.107 & -0.489 \\
\hline & 0.878 & 0.761 & 0.099 & 0.440 & 0.910 & 0.594 & 0.248 \\
\hline \multirow[t]{2}{*}{ Gap ( $\left.\Delta R R \_F-\Delta R R \_L\right)(t-1)$} & 0.002 & $-0.032^{\star \star \star}$ & -0.008 & $-0.074^{\star \star *}$ & -0.053 & 0.126 & -0.453 \\
\hline & 0.510 & 0.001 & 0.274 & 0.002 & 0.254 & 0.425 & 0.326 \\
\hline \multirow[t]{2}{*}{ Gap ( $\left(\Delta R R \_F-\Delta R R \_L\right)(t-2)$} & 0.002 & $-0.030^{* *}$ & -0.005 & $-0.069^{* \star *}$ & -0.064 & 0.355 & -0.301 \\
\hline & 0.423 & 0.024 & 0.495 & 0.002 & 0.131 & 0.113 & 0.429 \\
\hline \multirow{2}{*}{$\operatorname{Gap}\left(\Delta R R \_F-\Delta R R \_L\right)(t-3)$} & $-0.006^{*}$ & -0.011 & 0.000 & $-0.050^{* *}$ & -0.006 & $0.386^{*}$ & -0.194 \\
\hline & 0.068 & 0.362 & 0.993 & 0.046 & 0.897 & 0.080 & 0.584 \\
\hline sum coef $[t ; t-3]$ & -0.002 & $-0.078^{* *}$ & -0.025 & $-0.218^{\star \star *}$ & -0.119 & 0.76 & -1.44 \\
\hline$p$ value of sum test & 0.792 & 0.046 & 0.233 & 0.007 & 0.392 & 0.200 & 0.369 \\
\hline \multirow[t]{2}{*}{$\Delta$ average $R R$} & -0.000 & $0.021^{*}$ & -0.004 & 0.011 & 0.004 & 0.128 & -0.327 \\
\hline & 0.836 & 0.095 & 0.700 & 0.543 & 0.903 & 0.180 & 0.113 \\
\hline \multirow[t]{2}{*}{$\Delta$ average $R R(t-1)$} & 0.001 & $0.013^{*}$ & 0.006 & 0.017 & -0.031 & $-0.430^{*}$ & -0.149 \\
\hline & 0.600 & 0.065 & 0.441 & 0.359 & 0.358 & 0.071 & 0.128 \\
\hline \multirow[t]{2}{*}{$\Delta$ average $R R(t-2)$} & -0.001 & 0.001 & -0.011 & 0.020 & -0.026 & -0.276 & 0.060 \\
\hline & 0.795 & 0.903 & 0.420 & 0.409 & 0.544 & 0.155 & 0.621 \\
\hline \multirow[t]{2}{*}{$\Delta$ average $R R(t-3)$} & 0.001 & -0.005 & -0.002 & 0.004 & -0.020 & -0.032 & 0.046 \\
\hline & 0.721 & 0.380 & 0.816 & 0.800 & 0.592 & 0.779 & 0.770 \\
\hline \multirow[t]{2}{*}{ CBM } & 0.187 & $-1.095^{* *}$ & -0.333 & -1.887 & -1.024 & 7.858 & 6.505 \\
\hline & 0.169 & 0.046 & 0.403 & 0.149 & 0.589 & 0.306 & 0.371 \\
\hline \multirow[t]{2}{*}{ CBM (t-1) } & 0.222 & -0.367 & 0.035 & -0.139 & 0.810 & 3.481 & 2.013 \\
\hline & 0.141 & 0.635 & 0.923 & 0.916 & 0.653 & 0.634 & 0.791 \\
\hline \multirow[t]{2}{*}{ CBM $(t-2)$} & -0.041 & $1.221^{\star *}$ & 0.349 & -0.557 & -0.005 & 1.423 & 7.463 \\
\hline & 0.572 & 0.024 & 0.385 & 0.591 & 0.998 & 0.818 & 0.325 \\
\hline \multirow[t]{2}{*}{ CBM $(t-3)$} & -0.062 & -1.384 & 0.450 & -1.482 & -2.099 & -4.115 & 7.667 \\
\hline & 0.435 & 0.108 & 0.306 & 0.215 & 0.305 & 0.482 & 0.473 \\
\hline \multirow[t]{2}{*}{ RBM_inf } & -0.013 & -0.080 & 0.176 & -0.387 & 0.013 & 2.240 & 3.529 \\
\hline & 0.644 & 0.811 & 0.100 & 0.203 & 0.969 & 0.476 & 0.288 \\
\hline RBM_inf(t-1) & -0.009 & 0.092 & 0.120 & 0.031 & -0.577 & 2.472 & 3.141 \\
\hline & 0.706 & 0.672 & 0.239 & 0.911 & 0.267 & 0.325 & 0.207 \\
\hline RBM_inf(t-2) & 0.031 & 0.107 & 0.152 & 0.038 & -0.207 & 1.845 & 1.633 \\
\hline & 0.253 & 0.465 & 0.187 & 0.882 & 0.630 & 0.423 & 0.580 \\
\hline RBM_inf(t-3) & $-0.064^{*}$ & 0.057 & 0.048 & 0.005 & -0.770 & 0.671 & 0.876 \\
\hline & 0.065 & 0.703 & 0.684 & 0.982 & 0.153 & 0.764 & 0.759 \\
\hline MPM & -0.032 & 0.710 & 1.709 & $2.469^{*}$ & $7.044^{* *}$ & -1.503 & 1.461 \\
\hline & 0.612 & 0.320 & 0.135 & 0.054 & 0.019 & 0.824 & 0.836 \\
\hline MPM (t-1) & $0.107^{\star}$ & 0.459 & 0.829 & 0.830 & 1.282 & -1.828 & -0.732 \\
\hline & 0.084 & 0.542 & 0.146 & 0.561 & 0.516 & 0.760 & 0.922 \\
\hline MPM (t-2) & 0.027 & 0.924 & -1.023 & -0.857 & 5.075 & -1.246 & -4.010 \\
\hline & 0.672 & 0.302 & 0.144 & 0.702 & 0.149 & 0.824 & 0.665 \\
\hline MPM (t-3) & 0.020 & 0.373 & -0.706 & -0.190 & 1.558 & -0.415 & -2.800 \\
\hline & 0.752 & 0.763 & 0.368 & 0.887 & 0.620 & 0.927 & 0.746 \\
\hline GDP growth $(t-1)$ & $0.002^{* *}$ & $0.041^{* * *}$ & 0.027 & 0.024 & 0.067 & $0.432^{* *}$ & 0.218 \\
\hline & 0.024 & 0.000 & 0.174 & 0.337 & 0.181 & 0.029 & 0.161 \\
\hline Int. rate $(t-1)$ & & & & & & -0.128 & 0.489 \\
\hline & & & & & & 0.521 & 0.265 \\
\hline Exchange rate growth $(t-1)$ & 0.010 & 0.396 & -0.335 & 0.545 & -0.051 & & \\
\hline & 0.760 & 0.339 & 0.189 & 0.440 & 0.968 & & \\
\hline Int. rate differential ( $\mathrm{t}-1)$ & 0.001 & $0.007^{*}$ & -0.006 & -0.012 & 0.055 & & \\
\hline & 0.419 & 0.089 & 0.274 & 0.469 & 0.167 & & \\
\hline Sovereign rating $(t-1)$ & & $0.159^{* * *}$ & $0.022^{* *}$ & $0.311^{* *}$ & 0.304 & $0.524^{*}$ & $0.849^{* * *}$ \\
\hline & & 0.007 & 0.024 & 0.010 & 0.114 & 0.073 & 0.004 \\
\hline Capital inflows (t-1) & & & & & & -0.004 & -0.003 \\
\hline & & & & & & 0.271 & 0.511 \\
\hline ER regime (t-1) & & & & & & -2.735 & 1.515 \\
\hline & & & & & & 0.468 & 0.254 \\
\hline Constant & 0.024 & $-3.548^{\star \star *}$ & -0.016 & $-6.590^{* *}$ & -6.008 & & \\
\hline & 0.164 & 0.005 & 0.961 & 0.012 & 0.180 & & \\
\hline Country FE & Y & Y & Y & Y & Y & Y & Y \\
\hline Year FE & Y & Y & Y & Y & Y & Y & Y \\
\hline Observations & 2,826 & 2,773 & 2,702 & 2,703 & 2,763 & 2,545 & 2,196 \\
\hline R-squared & 0.048 & 0.121 & 0.030 & 0.110 & 0.105 & 0.117 & 0.141 \\
\hline Number of ifs_code & 51 & 49 & 48 & 48 & 49 & 48 & 48 \\
\hline
\end{tabular}

Note: ${ }^{*} p<0.10,{ }^{* *} p<0.05,{ }^{* * *} p<0.01$. Standard errors clustered at country level. Italic text displays the sum of the coefficients for all four lags, and the $p$-value of the sum test is displayed below rather that the standard errors as for the other coefficients in this table. 
Table A 5 - Testing for international spillover following tightening in FX reserve requirements

\begin{tabular}{|c|c|c|c|c|c|c|c|c|c|c|c|}
\hline Dependent variable & $\begin{array}{c}\text { (1) } \\
\text { total inflows } \\
\text { to GDP }\end{array}$ & $\begin{array}{c}\text { (2) } \\
\text { total inflows } \\
\text { to GDP }\end{array}$ & $\begin{array}{c}\text { (3) } \\
\text { total inflows } \\
\text { to GDP }\end{array}$ & $\begin{array}{c}(4) \\
\text { total inflows } \\
\text { to GDP }\end{array}$ & $\begin{array}{c}\text { (5) } \\
\text { total inflows } \\
\text { to GDP }\end{array}$ & $\begin{array}{c}\text { (6) } \\
\text { total inflows } \\
\text { to GDP } \\
\end{array}$ & $\begin{array}{c}\text { (7) } \\
\text { total inflows } \\
\text { to GDP }\end{array}$ & $\begin{array}{c}\text { (8) } \\
\text { FDI inflows } \\
\text { to GDP }\end{array}$ & $\begin{array}{c}\text { (9) } \\
\text { Portfolio } \\
\text { equity to } \\
\text { GDP }\end{array}$ & $\begin{array}{c}(10) \\
\text { Portfolio } \\
\text { debt to } \\
\text { GDP } \\
\end{array}$ & $\begin{array}{c}(11) \\
\text { Credit } \\
\text { inflows to } \\
\text { GDP }\end{array}$ \\
\hline Dep var. (t-1) & $\begin{array}{l}0.423^{* \star *} \\
(0.006)\end{array}$ & $\begin{array}{l}0.269^{* \star \star} \\
(0.011)\end{array}$ & $\begin{array}{c}0.422^{2 \star \star} \\
(0.006)\end{array}$ & $\begin{array}{c}0.352^{\star \star \star} \\
(0.005)\end{array}$ & $\begin{array}{l}0.322^{\star \star k} \\
(0.006)\end{array}$ & $\begin{array}{c}0.325^{\star k \star} \\
(0.007)\end{array}$ & $\begin{array}{l}0.352^{* k \star} \\
(0.006)\end{array}$ & $\begin{array}{c}0.232^{\star \star \star} \\
(0.001)\end{array}$ & $\begin{array}{l}0.559^{* \star *} \\
(0.005)\end{array}$ & $\begin{array}{c}-0.445^{\star * *} \\
(0.042)\end{array}$ & $\begin{array}{l}0.112^{* * *} \\
(0.018)\end{array}$ \\
\hline log_VIX & $\begin{array}{c}-0.056+ \\
(0.035)\end{array}$ & $\begin{array}{c}-0.007^{\star \star \star} \\
(0.002)\end{array}$ & $\begin{array}{l}-0.064 \\
(0.044)\end{array}$ & $\begin{array}{c}-0.059 \\
(0.041)\end{array}$ & $\begin{array}{l}-0.060 \\
(0.039)\end{array}$ & $\begin{array}{l}-0.057 \\
(0.039)\end{array}$ & $\begin{array}{c}-0.057+ \\
(0.035)\end{array}$ & $\begin{array}{c}0.001 \\
(0.004)\end{array}$ & $\begin{array}{l}-0.024 \\
(0.022)\end{array}$ & $\begin{array}{l}-0.019^{*} \\
(0.011)\end{array}$ & $\begin{array}{c}-0.022^{\star *} \\
(0.011)\end{array}$ \\
\hline Inflation (t-1) & $\begin{array}{c}-0.019^{\star * *} \\
(0.007)\end{array}$ & $\begin{array}{c}0.002 \\
(0.005)\end{array}$ & $\begin{array}{c}-0.016^{\star *} \\
(0.007)\end{array}$ & $\begin{array}{c}-0.027^{\star \star \star} \\
(0.009)\end{array}$ & $\begin{array}{c}-0.030^{\star \star \star} \\
(0.010)\end{array}$ & $\begin{array}{l}-0.015^{\star} \\
(0.008)\end{array}$ & $\begin{array}{c}-0.031+ \\
(0.019)\end{array}$ & $\begin{array}{c}0.014 \\
(0.019)\end{array}$ & $\begin{array}{l}-0.012 \\
(0.011)\end{array}$ & $\begin{array}{l}-0.005 \\
(0.005)\end{array}$ & $\begin{array}{c}-0.024+ \\
(0.015)\end{array}$ \\
\hline GDP growth $(\mathrm{t}-1)$ & $\begin{array}{c}0.001 \\
(0.001)\end{array}$ & $\begin{array}{c}0.001^{* * *} \\
(0.000)\end{array}$ & $\begin{array}{c}0.001 \\
(0.001)\end{array}$ & $\begin{array}{c}0.001 \\
(0.001)\end{array}$ & $\begin{array}{l}0.002+ \\
(0.001)\end{array}$ & $\begin{array}{l}0.002^{\star *} \\
(0.001)\end{array}$ & $\begin{array}{c}0.001 \\
(0.001)\end{array}$ & $\begin{array}{l}0.001^{* \star \star} \\
(0.000)\end{array}$ & $\begin{array}{l}-0.001 \\
(0.001)\end{array}$ & $\begin{array}{l}-0.000 \\
(0.001)\end{array}$ & $\begin{array}{l}0.002^{* \star *} \\
(0.001)\end{array}$ \\
\hline Interest rate $(\mathrm{t}-1)$ & $\begin{array}{c}-0.000 \\
(0.000)\end{array}$ & $\begin{array}{c}-0.000 \\
(0.000)\end{array}$ & $\begin{array}{l}-0.000 \\
(0.000)\end{array}$ & $\begin{array}{c}-0.000 \\
(0.000)\end{array}$ & $\begin{array}{c}-0.000 \\
(0.000)\end{array}$ & $\begin{array}{c}0.000 \\
(0.001)\end{array}$ & $\begin{array}{c}-0.000 \\
(0.001)\end{array}$ & $\begin{array}{l}0.000^{*} \\
(0.000)\end{array}$ & $\begin{array}{l}-0.000 \\
(0.000)\end{array}$ & $\begin{array}{c}-0.000 \\
(0.000)\end{array}$ & $\begin{array}{l}0.000^{*} \\
(0.000)\end{array}$ \\
\hline RBM_inf on respective flow (t-1) & $\begin{array}{c}0.004 \\
(0.007)\end{array}$ & $\begin{array}{c}0.003 \\
(0.002)\end{array}$ & $\begin{array}{c}0.004 \\
(0.008)\end{array}$ & $\begin{array}{c}0.001 \\
(0.007)\end{array}$ & $\begin{array}{c}0.003 \\
(0.007)\end{array}$ & $\begin{array}{c}0.000 \\
(0.006)\end{array}$ & $\begin{array}{c}-0.002 \\
(0.006)\end{array}$ & $\begin{array}{l}0.001^{*} \\
(0.001)\end{array}$ & $\begin{array}{c}0.002 \\
(0.002)\end{array}$ & $\begin{array}{c}0.000 \\
(0.001)\end{array}$ & $\begin{array}{l}-0.002 \\
(0.002)\end{array}$ \\
\hline RR gap spillover (t-1) & $\begin{array}{l}-0.002 \\
(0.002)\end{array}$ & $\begin{array}{c}0.000 \\
(0.000)\end{array}$ & & & & & $\begin{array}{c}-0.001 \\
(0.002)\end{array}$ & $\begin{array}{l}-0.001 \\
(0.001)\end{array}$ & $\begin{array}{l}-0.000 \\
(0.000)\end{array}$ & $\begin{array}{c}-0.000 \\
(0.001)\end{array}$ & $\begin{array}{c}0.000 \\
(0.002)\end{array}$ \\
\hline RR gap spillover (t-2) & & & & $\begin{array}{l}-0.000 \\
(0.001)\end{array}$ & & & $\begin{array}{l}-0.000 \\
(0.001)\end{array}$ & & & & \\
\hline RR gap spillover (t-3) & & & & & $\begin{array}{l}-0.000 \\
(0.003)\end{array}$ & & $\begin{array}{l}-0.001 \\
(0.002)\end{array}$ & & & & \\
\hline RR gap spillover (t-4) & & & & & & $\begin{array}{c}0.006 \\
(0.004)\end{array}$ & $\begin{array}{l}0.005^{\star} \\
(0.003)\end{array}$ & & & & \\
\hline RR gap spillover (t-1) (fixed corr.) & & & $\begin{array}{c}-0.003+ \\
(0.002) \\
\end{array}$ & & & & & & & & \\
\hline Observations & 2235 & 651 & 1851 & 2188 & 2141 & 2094 & 1962 & 2228 & 2179 & 2175 & 2228 \\
\hline Country FE & Y & Y & Y & $\mathrm{Y}$ & $\mathrm{Y}$ & $\mathrm{Y}$ & Y & $\mathrm{Y}$ & Y & $\mathrm{Y}$ & Y \\
\hline Country sample & All & EME & All & All & All & All & All & All & All & All & All \\
\hline
\end{tabular}

Note: ${ }^{*} p<0.10,{ }^{* *} p<0.05,{ }^{* * *} p<0.01$. Standard errors clustered at country level. The RR gap spillover variable is computed as the weighted sum of tightening actions in FX reserve requirements in other countries, with the weights representing the similarly between the two countries, proxied by the correlation of inflows to both countries. 
Table A 6 - First stage regressions (Drivers of RR adjustments)

\begin{tabular}{|c|c|c|c|c|c|c|c|c|c|}
\hline \multirow[t]{2}{*}{ Dep. var. } & \multicolumn{9}{|c|}{ Change in RR gap (FX - LC) } \\
\hline & (1) & (2) & (3) & (4) & $(5)$ & $(6)$ & (7) & (8) & (9) \\
\hline \multirow[t]{2}{*}{$\operatorname{Gap}\left(\Delta R R \_F-\Delta R R \_L\right)(t-1)$} & $-4.681^{\star \star *}$ & $-4.681^{* \star *}$ & $-4.697^{\star \star *}$ & $-4.679^{* \star *}$ & -4.092 & $-4.545^{\star \star *}$ & $-4.660^{* * *}$ & $-4.360^{* \star *}$ & $-4.629^{* *}$ \\
\hline & 0.007 & 0.007 & 0.007 & 0.007 & 0.121 & 0.010 & 0.005 & 0.001 & 0.029 \\
\hline \multirow[t]{2}{*}{$\Delta$ Interest rate } & 0.096 & 0.096 & 0.096 & 0.096 & 0.359 & 0.238 & 0.231 & 0.224 & 0.105 \\
\hline & 0.197 & 0.197 & 0.197 & 0.198 & 0.199 & 0.181 & 0.185 & 0.177 & 0.130 \\
\hline \multirow[t]{2}{*}{ GDP growth (t-1) } & 0.010 & 0.010 & 0.011 & 0.010 & -0.029 & 0.010 & 0.012 & 0.012 & -0.000 \\
\hline & 0.432 & 0.432 & 0.436 & 0.438 & 0.172 & 0.839 & 0.796 & 0.771 & 0.942 \\
\hline \multirow{2}{*}{ Exchange rate growth $(t-1)$} & -0.074 & -0.074 & -0.072 & -0.075 & $-0.865^{*}$ & 0.112 & 0.184 & 0.133 & -0.261 \\
\hline & 0.841 & 0.841 & 0.845 & 0.837 & 0.066 & 0.889 & 0.798 & 0.864 & 0.385 \\
\hline \multirow[t]{2}{*}{ Credit growth (t-1) } & 0.003 & 0.003 & 0.003 & 0.003 & 0.011 & 0.005 & 0.005 & 0.004 & 0.000 \\
\hline & 0.257 & 0.257 & 0.259 & 0.257 & 0.376 & 0.317 & 0.318 & 0.322 & 0.973 \\
\hline \multirow[t]{2}{*}{ Total inflows to GDP (t-1) } & -0.000 & -0.000 & & & & & & & \\
\hline & 0.160 & 0.160 & & & & & & & \\
\hline \multirow[t]{2}{*}{ Port debtinflows to GDP (t-1) } & & & -0.005 & & -0.007 & -0.005 & -0.001 & 0.001 & 0.000 \\
\hline & & & 0.434 & & 0.275 & 0.367 & 0.847 & 0.913 & 0.907 \\
\hline \multirow[t]{2}{*}{ Other inflows to GDP (t-1) } & & & & -0.001 & & & & & \\
\hline & & & & 0.368 & & & & & \\
\hline \multirow[t]{2}{*}{ Net FX position (t-1) } & & & & & 0.004 & & & & \\
\hline & & & & & 0.236 & & & & \\
\hline \multirow[t]{2}{*}{$\Delta \mathrm{FX}$ _loans_share (t-1) } & & & & & & -0.008 & & & \\
\hline & & & & & & 0.417 & & & \\
\hline \multirow[t]{2}{*}{$\Delta \mathrm{FX}$ liab_share (t-1) } & & & & & & & 0.018 & & \\
\hline & & & & & & & 0.196 & & \\
\hline \multirow[t]{2}{*}{ FX_liab_share (t-1) } & & & & & & & & 0.000 & \\
\hline & & & & & & & & 0.982 & \\
\hline \multirow[t]{2}{*}{ NFC debt growth (t-1) } & & & & & & & & & -0.009 \\
\hline & & & & & & & & & 0.962 \\
\hline \multirow[t]{2}{*}{ Constant } & -0.105 & -0.105 & -0.110 & -0.106 & -0.290 & 0.141 & 0.076 & 0.090 & -0.007 \\
\hline & 0.321 & 0.321 & 0.313 & 0.316 & 0.312 & 0.516 & 0.714 & 0.862 & 0.897 \\
\hline Observations & 2,704 & 2,704 & 2,638 & 2,704 & 766 & 804 & 878 & 902 & 2,490 \\
\hline R-squared & 0.045 & 0.045 & 0.046 & 0.045 & 0.287 & 0.118 & 0.111 & 0.104 & 0.046 \\
\hline Number of ifs_code & 49 & 49 & 48 & 49 & 37 & 24 & 26 & 26 & 44 \\
\hline
\end{tabular}

Note: ${ }^{*} p<0.10,{ }^{* *} p<0.05,{ }^{* * *} p<0.01$. Standard errors clustered at country level. Model run with country and year fixed effects. The dependent variable is the change in the RR gap (continuous). 
Table A 7 - Direct and indirect effect - the residual method

\begin{tabular}{|c|c|c|c|c|c|c|c|c|c|c|c|}
\hline$\underline{\text { Dependent variable }}$ & $\begin{array}{c}\text { (1) } \\
\text { CB_tobanks_Flows }\end{array}$ & $\begin{array}{c}(2) \\
\Delta F X \_ \text {loans_share }\end{array}$ & $\begin{array}{c}(3) \\
\Delta \mathrm{FX} \text { _liab_share } \\
\end{array}$ & $\begin{array}{c}\text { (4) } \\
\Delta \text { Net_FX_pos_FSI }\end{array}$ & $\begin{array}{c}\text { (5) } \\
\text { NFC debt } \\
\text { growth } \\
\end{array}$ & $\begin{array}{c}(6) \\
\text { CB_tononbanks_ } \\
\text { Flows } \\
\end{array}$ & $\begin{array}{c}\text { (7) } \\
\text { equity flow }\end{array}$ & $\begin{array}{c}\text { (8) } \\
\text { portfolio debt } \\
\text { flow } \\
\end{array}$ & $\begin{array}{c}\text { (9) } \\
\text { creditflow } \\
\end{array}$ & $\begin{array}{c}(10) \\
\text { ER deviation } \\
3 Y \\
\end{array}$ & $\begin{array}{c}(11) \\
\text { ER deviation } \\
5 Y \\
\end{array}$ \\
\hline \multirow{2}{*}{ Residual from gap reg } & -0.057 & -0.151 & -0.039 & $-1.509^{\star \star *}$ & 0.003 & -0.006 & -0.002 & -0.058 & -0.049 & 0.207 & -0.457 \\
\hline & 0.108 & 0.476 & 0.199 & 0.000 & 0.256 & 0.772 & 0.844 & 0.223 & 0.370 & 0.304 & 0.389 \\
\hline \multirow[t]{2}{*}{ Residual from gap reg ( $(-1)$} & $-0.070^{* *}$ & -0.102 & -0.063 & 0.214 & 0.004 & $-0.041^{\star \star *}$ & -0.002 & $-0.077^{\star \star *}$ & -0.052 & $0.558^{\star * *}$ & -0.459 \\
\hline & 0.043 & 0.451 & 0.201 & 0.237 & 0.337 & 0.001 & 0.862 & 0.002 & 0.369 & 0.001 & 0.393 \\
\hline \multirow[t]{2}{*}{ Residual from gap reg ( $(-2)$} & -0.038 & -0.146 & $-0.117^{\star \star *}$ & -0.541 & 0.003 & -0.024 & 0.004 & $-0.075^{* *}$ & -0.069 & $0.860^{* *}$ & -0.279 \\
\hline & 0.271 & 0.266 & 0.002 & 0.122 & 0.301 & 0.103 & 0.772 & 0.022 & 0.229 & 0.011 & 0.539 \\
\hline \multirow[t]{2}{*}{ Residual from gap reg ( $(-3)$} & $-0.115^{* *}$ & -0.054 & 0.025 & $-0.485^{* *}$ & $-0.009^{*}$ & $-0.042^{* * *}$ & -0.001 & $-0.078^{\star *}$ & $-0.114^{*}$ & $0.753^{\star \star *}$ & -0.050 \\
\hline & 0.011 & 0.223 & 0.354 & 0.043 & 0.074 & 0.008 & 0.929 & 0.015 & 0.091 & 0.008 & 0.900 \\
\hline sum coef $[t ; t-3]$ & $-0.28^{* *}$ & -0.453 & $-0.194^{* \star}$ & $-2.321^{* \star *}$ & 0.001 & $-0.113^{* *}$ & -0.001 & $-0.288^{* *}$ & -0.284 & $2.378^{\star \star \star}$ & -1.245 \\
\hline$p$ value of sum test & 0.037 & 0.365 & 0.015 & 0.001 & 0.950 & 0.022 & 0.980 & 0.020 & 0.160 & 0.002 & 0.507 \\
\hline \multirow{2}{*}{ Residual from average RR reg } & 0.048 & 0.332 & $0.048^{* *}$ & -0.039 & -0.000 & $0.022^{*}$ & -0.013 & 0.016 & 0.004 & -0.074 & -0.309 \\
\hline & 0.240 & 0.474 & 0.042 & 0.688 & 0.881 & 0.096 & 0.329 & 0.513 & 0.945 & 0.651 & 0.192 \\
\hline \multirow[t]{2}{*}{ Residual from average RR reg $(\mathrm{t}-1)$} & 0.059 & 0.169 & 0.126 & 0.036 & 0.000 & 0.022 & -0.003 & 0.001 & -0.037 & $-0.748^{*}$ & -0.063 \\
\hline & 0.171 & 0.393 & 0.152 & 0.762 & 0.915 & 0.115 & 0.771 & 0.947 & 0.493 & 0.051 & 0.587 \\
\hline \multirow[t]{2}{*}{ Residual from average $\mathrm{RR}$ reg (t-2) } & -0.003 & 0.157 & 0.041 & 0.472 & -0.000 & 0.007 & -0.021 & 0.014 & -0.014 & $-0.524^{*}$ & 0.124 \\
\hline & 0.954 & 0.324 & 0.209 & 0.328 & 0.913 & 0.583 & 0.241 & 0.680 & 0.796 & 0.086 & 0.521 \\
\hline \multirow[t]{2}{*}{ Residual from average $R R$ reg $(t-3)$} & 0.005 & -0.037 & -0.042 & 0.200 & 0.000 & 0.000 & -0.008 & -0.014 & -0.043 & -0.188 & 0.049 \\
\hline & 0.905 & 0.568 & 0.239 & 0.346 & 0.955 & 0.966 & 0.555 & 0.605 & 0.303 & 0.253 & 0.805 \\
\hline Policy controls & $\mathrm{Y}$ & $\mathrm{Y}$ & $\mathrm{Y}$ & $\mathrm{Y}$ & $\mathrm{Y}$ & $\mathrm{Y}$ & $\mathrm{Y}$ & $\mathrm{Y}$ & $\mathrm{Y}$ & $\mathrm{Y}$ & $\mathrm{Y}$ \\
\hline Other controls & $\mathrm{Y}$ & Y & $\mathrm{Y}$ & $\mathrm{Y}$ & $\mathrm{Y}$ & $\mathrm{Y}$ & Y & $\mathrm{Y}$ & $\mathrm{Y}$ & Y & $\mathrm{Y}$ \\
\hline Country \& year FE & $\mathrm{Y}$ & $\mathrm{Y}$ & $\mathrm{Y}$ & $\mathrm{Y}$ & $\mathrm{Y}$ & $\mathrm{Y}$ & $\mathrm{Y}$ & $\mathrm{Y}$ & $\mathrm{Y}$ & Y & $\mathrm{Y}$ \\
\hline Observations & 2,491 & 808 & 882 & 694 & 2,430 & 2,491 & 2,431 & 2,432 & 2,491 & 2,392 & 2,098 \\
\hline R-squared & 0.119 & 0.053 & 0.058 & 0.060 & 0.060 & 0.122 & 0.037 & 0.126 & 0.106 & 0.151 & 0.142 \\
\hline Number of ifs_code & 47 & 24 & 25 & 32 & 45 & 47 & 46 & 46 & 47 & 47 & 47 \\
\hline
\end{tabular}

Note: ${ }^{*} p<0.10,{ }^{* *} p<0.05,{ }^{* * *} p<0.01$. Standard errors clustered at country level. Italic text displays the sum of the coefficients for all four lags, and the $p$-value of the sum test is displayed below rather that the standard errors as for the other coefficients in this table. 
Table A 8 - Non linear models

\begin{tabular}{|c|c|c|c|c|c|c|c|c|c|c|c|c|c|c|}
\hline \multirow[b]{2}{*}{ Dependent variable } & \multicolumn{2}{|c|}{ CB_tobanks_Flows } & \multicolumn{2}{|c|}{$\Delta$ FX_loans_share } & \multicolumn{2}{|c|}{$\Delta$ FX_liab_share } & \multicolumn{2}{|c|}{$\Delta$ Net_FX_pos_FSI } & & & & & & \\
\hline & Baseline & $\begin{array}{c}\text { Scaled by } \\
\text { Av_RR }\end{array}$ & Baseline & $\begin{array}{c}\text { Scaled by } \\
\text { Av_RR }\end{array}$ & Baseline & $\begin{array}{c}\text { Scaled by } \\
\text { Av_RR }\end{array}$ & Baseline & $\begin{array}{c}\text { Scaled by } \\
\text { Av_RR }\end{array}$ & & & & & & \\
\hline sum coef $[t ; t-3]$ & -0.104 & -0.019 & -0.226 & -0.041 & $-0.111^{*}$ & $-0.023^{* *}$ & $-1.62^{* * *}$ & $-0.267^{* *}$ & & & & & & \\
\hline \multirow[t]{2}{*}{$p$ value of sum test } & 0.319 & 0.261 & 0.443 & 0.452 & 0.083 & 0.049 & 0.008 & 0.033 & & & & & & \\
\hline & \multicolumn{2}{|c|}{ NFC debt growth } & \multicolumn{2}{|c|}{$\begin{array}{c}\text { CB_tononbanks_Flo } \\
\text { ws }\end{array}$} & \multicolumn{2}{|c|}{ equity flow } & \multicolumn{2}{|c|}{ portfolio debt flow } & \multicolumn{2}{|c|}{ credit flow } & \multicolumn{2}{|c|}{ ER dev $3 Y$} & \multicolumn{2}{|c|}{ ER dev $5 Y$} \\
\hline Dependent variable & Baseline & $\begin{array}{c}\text { Scaled by } \\
\text { Av_RR }\end{array}$ & Baseline & $\begin{array}{c}\text { Scaled by } \\
\text { Av_RR }\end{array}$ & Baseline & $\begin{array}{c}\text { Scaled by } \\
\text { Av_RR }\end{array}$ & Baseline & $\begin{array}{c}\text { Scaled by } \\
\text { Av_RR }\end{array}$ & Baseline & $\begin{array}{c}\text { Scaled by } \\
\text { Av_RR }\end{array}$ & Baseline & $\begin{array}{c}\text { Scaled by } \\
\text { Av_RR }\end{array}$ & Baseline & $\begin{array}{c}\text { Scaled by } \\
\text { Av_RR }\end{array}$ \\
\hline sum coef $[t ; t-3]$ & -0.002 & -0.001 & $-0.078^{* *}$ & $-0.014^{\star * *}$ & -0.025 & -0.004 & $-0.218^{* * *}$ & $-0.037^{* * *}$ & -0.119 & -0.023 & 0.76 & $0.189^{* \star}$ & -1.44 & -0.23 \\
\hline$p$ value of sum test & 0.792 & 0.800 & 0.046 & 0.009 & 0.233 & 0.373 & 0.007 & 0.001 & 0.392 & 0.242 & 0.200 & 0.050 & 0.369 & 0.421 \\
\hline
\end{tabular}

Note: ${ }^{*} p<0.10,{ }^{* *} p<0.05,{ }^{* * *} p<0.01$. Standard errors clustered at country level. Italic text displays the sum of the coefficients for all four lags, and the $p$-value of the sum test is displayed below rather that the standard errors as for the other coefficients in this table. 
Table A 9 - The direct effect of reserve requirements: intensity-based measures vs. easing/tightening binary variables

\begin{tabular}{|c|c|c|c|c|c|c|c|c|}
\hline \multirow{3}{*}{$\begin{array}{l}\text { Dependent var: } \\
\text { RR variable type: }\end{array}$} & \multicolumn{2}{|c|}{ Inflows to banks } & \multicolumn{2}{|c|}{$\Delta F X$ loans share } & \multicolumn{2}{|c|}{$\Delta \mathrm{FX}$ liab share } & \multicolumn{2}{|c|}{$\Delta$ NetFX position } \\
\hline & (1) & $(2)$ & (3) & (4) & (5) & (6) & (7) & (8) \\
\hline & rates & binary & rates & binary & rates & binary & rates & binary \\
\hline \multirow[t]{2}{*}{$\Delta \mathrm{RR} F X$ liabilities } & -0.003 & $0.296^{*}$ & -0.008 & 0.065 & 0.001 & 0.126 & $-1.458^{* * *}$ & -2.386 \\
\hline & 0.898 & 0.099 & 0.801 & 0.563 & 0.968 & 0.641 & 0.000 & 0.258 \\
\hline \multirow[t]{2}{*}{$\Delta \mathrm{RR} F X$ liabilities $(\mathrm{t}-1)$} & -0.014 & -0.187 & 0.015 & 0.032 & 0.008 & 0.330 & $0.303^{* *}$ & 1.051 \\
\hline & 0.569 & 0.233 & 0.775 & 0.920 & 0.828 & 0.255 & 0.048 & 0.245 \\
\hline \multirow[t]{2}{*}{$\Delta$ RR FX liabilities $(t-2)$} & -0.030 & -0.031 & -0.036 & 0.108 & -0.026 & 0.022 & -0.239 & -0.056 \\
\hline & 0.222 & 0.866 & 0.319 & 0.706 & 0.582 & 0.914 & 0.198 & 0.941 \\
\hline \multirow[t]{2}{*}{$\Delta \mathrm{RR} F X$ liabilities $(t-3)$} & -0.031 & $-0.265^{*}$ & -0.036 & -0.059 & -0.015 & 0.037 & -0.200 & $-0.677^{*}$ \\
\hline & 0.310 & 0.095 & 0.453 & 0.616 & 0.445 & 0.834 & 0.109 & 0.079 \\
\hline sum coef [t;t-3] & -0.078 & -0.187 & -0.065 & 0.146 & -0.032 & $0.515^{\star \star}$ & $-1.594^{\star * *}$ & -2.068 \\
\hline$p$ value of sum test & 0.36 & 0.72 & 0.62 & 0.81 & 0.36 & 0.01 & 0.00 & 0.37 \\
\hline \multirow[t]{2}{*}{$\Delta \mathrm{RR} L C$ liabilities } & $0.038^{*}$ & $0.189^{*}$ & 0.015 & 0.063 & -0.018 & 0.041 & 0.353 & 1.703 \\
\hline & 0.074 & 0.086 & 0.806 & 0.640 & 0.634 & 0.704 & 0.298 & 0.258 \\
\hline \multirow[t]{2}{*}{$\Delta R R$ LC liabilities ( $(-1)$} & 0.060 & 0.283 & 0.025 & 0.425 & $0.148^{*}$ & $0.416^{\star \star *}$ & -0.018 & -1.837 \\
\hline & 0.240 & 0.132 & 0.713 & 0.173 & 0.097 & 0.003 & 0.907 & 0.141 \\
\hline \multirow[t]{2}{*}{$\Delta \mathrm{RR}$ LC liabilities ( $\mathrm{t}-2)$} & 0.004 & 0.021 & 0.080 & 0.339 & 0.077 & $0.252^{\star * *}$ & $0.410^{* *}$ & 0.581 \\
\hline & 0.918 & 0.886 & 0.224 & 0.217 & 0.203 & 0.000 & 0.025 & 0.216 \\
\hline \multirow[t]{2}{*}{$\Delta \mathrm{RR}$ LC liabilities $(\mathrm{t}-3)$} & 0.026 & 0.033 & 0.061 & 0.170 & 0.028 & -0.080 & 0.086 & 0.713 \\
\hline & 0.625 & 0.780 & 0.189 & 0.295 & 0.233 & 0.672 & 0.519 & 0.155 \\
\hline sum coef $[t ; t-3]$ & 0.128 & 0.526 & 0.181 & $0.997^{*}$ & 0.235 & 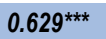 & $0.831^{* *}$ & 1.16 \\
\hline$p$ value of sum test & 0.42 & 0.22 & 0.43 & 0.07 & 0.11 & 0.01 & 0.04 & 0.32 \\
\hline \multirow[t]{2}{*}{$\Delta$ single RR } & 0.036 & -0.016 & 0.784 & 2.613 & $0.074^{\star \star \star}$ & 0.295 & -0.118 & -0.348 \\
\hline & 0.613 & 0.950 & 0.367 & 0.234 & 0.008 & 0.175 & 0.496 & 0.582 \\
\hline \multirow[t]{2}{*}{$\Delta$ single $R R(t-1)$} & 0.044 & -0.024 & 0.468 & 1.956 & 0.099 & 0.316 & -0.156 & -0.751 \\
\hline & 0.537 & 0.933 & 0.266 & 0.272 & 0.312 & 0.537 & 0.615 & 0.444 \\
\hline \multirow[t]{2}{*}{$\Delta$ single $R R(t-2)$} & 0.047 & 0.088 & 0.524 & 2.684 & 0.032 & 0.199 & 0.731 & 1.511 \\
\hline & 0.643 & 0.680 & 0.299 & 0.221 & 0.610 & 0.613 & 0.380 & 0.232 \\
\hline \multirow{2}{*}{$\Delta$ single $R R(t-3)$} & 0.071 & 0.219 & -0.139 & -0.517 & -0.052 & 0.306 & 0.390 & 2.168 \\
\hline & 0.359 & 0.419 & 0.494 & 0.543 & 0.481 & 0.324 & 0.381 & 0.185 \\
\hline sum coef [t;t-3] & 0.198 & 0.267 & 1.637 & 6.736 & 0.153 & 1.116 & 0.847 & 2.58 \\
\hline$p$ value of sum test & 0.49 & 0.54 & 0.30 & 0.21 & 0.26 & 0.11 & 0.29 & 0.18 \\
\hline Policy controls & $Y$ & $\mathrm{Y}$ & $\mathrm{Y}$ & $Y$ & $\mathrm{Y}$ & $Y$ & $\mathrm{Y}$ & $Y$ \\
\hline Other controls & $Y$ & $Y$ & $Y$ & $Y$ & $Y$ & $Y$ & Y & $Y$ \\
\hline Country \& year FE & $Y$ & $Y$ & $Y$ & $Y$ & $Y$ & $Y$ & Y & $Y$ \\
\hline Observations & 2,773 & 2,773 & 891 & 891 & 1,029 & 1,029 & 797 & 797 \\
\hline R-squared & 0.118 & 0.118 & 0.114 & 0.101 & 0.060 & 0.055 & 0.064 & 0.035 \\
\hline Number of ifs_code & 49 & 49 & 25 & 25 & 29 & 29 & 35 & 35 \\
\hline
\end{tabular}

Note: ${ }^{*} p<0.10,{ }^{* *} p<0.05,{ }^{* * *} p<0.01$. Standard errors clustered at country level. Italic text displays the sum of the coefficients for all four lags, and the $p$-value of the sum test is displayed below rather that the standard errors as for the other coefficients in this table. 
Table A 10 - The indirect effect of reserve requirements: intensity-based measures vs. easing/tightening binary variables

\begin{tabular}{|c|c|c|c|c|c|c|c|c|c|c|c|c|c|c|}
\hline \multirow{3}{*}{$\begin{array}{l}\text { Dependent var: } \\
\text { RR variable type: }\end{array}$} & \multicolumn{2}{|c|}{ NFC debt growth } & \multicolumn{2}{|c|}{ Inflows to non-banks } & \multicolumn{2}{|c|}{ Equity Inflows } & \multicolumn{2}{|c|}{ Debt Inflows } & \multicolumn{2}{|c|}{ Other Inflows } & \multicolumn{2}{|c|}{ ER deviation $3 Y$} & \multicolumn{2}{|c|}{ ER deviation $5 Y$} \\
\hline & (1) & (2) & (3) & (4) & (5) & (6) & (7) & (8) & (9) & (10) & (11) & (12) & (13) & (14) \\
\hline & rates & binary & rates & binary & rates & binary & rates & binary & rates & binary & rates & binary & rates & binary \\
\hline \multirow[t]{2}{*}{$\Delta$ RR FX liabilities } & 0.000 & 0.050 & 0.009 & 0.110 & -0.012 & -0.067 & -0.011 & -0.060 & 0.006 & 0.291 & 0.023 & $3.960^{*}$ & -0.699 & -3.148 \\
\hline & 0.950 & 0.126 & 0.687 & 0.118 & 0.129 & 0.189 & 0.798 & 0.592 & 0.872 & 0.307 & 0.928 & 0.090 & 0.207 & 0.307 \\
\hline \multirow[t]{2}{*}{$\Delta$ RR FX liabilities (t-1) } & 0.003 & 0.014 & $-0.024^{* *}$ & $-0.092^{*}$ & -0.003 & 0.048 & $-0.059^{* \star *}$ & $-0.205^{\star *}$ & -0.062 & -0.048 & -0.130 & $2.441^{* *}$ & -0.531 & -2.224 \\
\hline & 0.464 & 0.406 & 0.016 & 0.057 & 0.741 & 0.594 & 0.001 & 0.029 & 0.160 & 0.872 & 0.432 & 0.020 & 0.281 & 0.408 \\
\hline \multirow[t]{2}{*}{$\Delta$ RR FX liabilities (t-2) } & 0.001 & $0.024^{\star *}$ & $-0.028^{* *}$ & -0.079 & -0.006 & $-0.095^{* *}$ & $-0.053^{* * *}$ & $-0.157^{*}$ & $-0.077^{*}$ & -0.193 & 0.207 & $4.155^{\star}$ & -0.276 & -0.641 \\
\hline & 0.448 & 0.045 & 0.017 & 0.357 & 0.403 & 0.035 & 0.002 & 0.085 & 0.074 & 0.372 & 0.234 & 0.058 & 0.431 & 0.708 \\
\hline \multirow[t]{2}{*}{$\Delta$ RR FX liabilities ( $(t-3)$} & $-0.006^{*}$ & 0.002 & -0.013 & -0.086 & -0.000 & 0.028 & $-0.046^{* \star}$ & $-0.209^{*}$ & -0.020 & -0.278 & $0.372^{*}$ & 4.597 & -0.150 & 0.259 \\
\hline & 0.087 & 0.946 & 0.260 & 0.175 & 0.946 & 0.701 & 0.014 & 0.076 & 0.722 & 0.318 & 0.061 & 0.205 & 0.658 & 0.794 \\
\hline sum coef $[t ; t-3]$ & -0.002 & 0.09 & -0.056 & -0.147 & -0.021 & -0.086 & $-0.169^{\text {** }}$ & -0.631 & -0.153 & -0.228 & 0.47 & $15.153^{*}$ & -1.66 & -5.75 \\
\hline$p$ value of sum test & 0.81 & 0.15 & 0.19 & 0.39 & 0.36 & 0.64 & 0.02 & 0.06 & 0.27 & 0.76 & 0.42 & 0.10 & 0.33 & 0.48 \\
\hline \multirow{2}{*}{$\Delta R R L C$ liabilities } & -0.002 & -0.043 & $0.020^{*}$ & $0.168^{* * *}$ & 0.012 & 0.033 & 0.040 & $0.354^{\star \star \star}$ & -0.004 & -0.117 & 0.256 & 1.245 & 0.137 & 1.289 \\
\hline & 0.705 & 0.136 & 0.062 & 0.007 & 0.190 & 0.535 & 0.224 & 0.001 & 0.900 & 0.539 & 0.187 & 0.234 & 0.577 & 0.443 \\
\hline \multirow{2}{*}{$\Delta R R L C$ liabilities (t-1) } & -0.004 & 0.014 & $0.049^{\star * *}$ & $0.137^{*}$ & $0.017^{\star \star}$ & $0.129^{* *}$ & $0.121^{\star \star *}$ & $0.292^{\star \star * \star}$ & 0.056 & 0.211 & -0.422 & 0.318 & 0.237 & 1.647 \\
\hline & 0.398 & 0.455 & 0.000 & 0.066 & 0.038 & 0.029 & 0.000 & 0.008 & 0.355 & 0.318 & 0.161 & 0.782 & 0.431 & 0.487 \\
\hline \multirow{2}{*}{$\Delta R R L C$ liabilities $(t-2)$} & $-0.007^{* \star * *}$ & $-0.033^{* *}$ & $0.038^{\star \star}$ & 0.034 & 0.013 & -0.003 & $0.117^{\star \star *}$ & $0.244^{*}$ & 0.065 & 0.186 & -0.604 & -0.357 & 0.264 & 0.857 \\
\hline & 0.001 & 0.019 & 0.031 & 0.757 & 0.127 & 0.955 & 0.005 & 0.075 & 0.227 & 0.339 & 0.116 & 0.778 & 0.511 & 0.735 \\
\hline \multirow{2}{*}{$\Delta R R$ LC liabilities ( $t-3)$} & 0.004 & -0.008 & 0.014 & 0.060 & 0.013 & 0.041 & $0.091^{* * *}$ & 0.155 & -0.030 & 0.064 & -0.449 & 2.478 & 0.304 & 1.406 \\
\hline & 0.159 & 0.746 & 0.337 & 0.426 & 0.131 & 0.436 & 0.004 & 0.184 & 0.501 & 0.783 & 0.110 & 0.230 & 0.524 & 0.571 \\
\hline sum coef $[t ; t-3]$ & -0.009 & $-0.07^{\star * *}$ & $0.121^{* * *}$ & $0.399^{* *}$ & $0.055^{*}$ & 0.2 & $0.369^{\star \star \star \star}$ & $1.045^{\star \star *}$ & 0.087 & 0.344 & -1.219 & 3.684 & 0.942 & 5.199 \\
\hline$p$ value of sum test & 0.21 & 0.00 & 0.01 & 0.05 & 0.06 & 0.10 & 0.00 & 0.01 & 0.60 & 0.56 & 0.16 & 0.48 & 0.46 & 0.56 \\
\hline \multirow[t]{2}{*}{$\Delta$ single $R R$} & -0.001 & 0.009 & 0.009 & 0.051 & $-0.029^{\star}$ & -0.046 & 0.026 & 0.142 & 0.023 & -0.583 & -0.266 & -0.338 & -0.232 & -0.057 \\
\hline & 0.704 & 0.253 & 0.689 & 0.600 & 0.087 & 0.580 & 0.207 & 0.397 & 0.821 & 0.170 & 0.226 & 0.617 & 0.164 & 0.953 \\
\hline \multirow[t]{2}{*}{$\Delta$ single RR (t-1) } & 0.000 & 0.008 & -0.011 & $-0.098^{*}$ & 0.001 & $0.164^{*}$ & $-0.036^{\star}$ & -0.186 & -0.032 & -0.192 & -0.267 & -0.754 & -0.034 & 0.038 \\
\hline & 0.996 & 0.328 & 0.352 & 0.062 & 0.972 & 0.085 & 0.075 & 0.287 & 0.570 & 0.585 & 0.263 & 0.333 & 0.802 & 0.957 \\
\hline \multirow[t]{2}{*}{$\Delta$ single $R R(t-2)$} & 0.005 & 0.012 & -0.010 & -0.013 & -0.015 & -0.003 & -0.003 & 0.148 & 0.045 & 0.170 & -0.009 & 0.158 & 0.131 & 0.701 \\
\hline & 0.471 & 0.253 & 0.644 & 0.812 & 0.340 & 0.942 & 0.910 & 0.451 & 0.612 & 0.569 & 0.965 & 0.806 & 0.269 & 0.170 \\
\hline \multirow[t]{2}{*}{$\Delta$ single $R R(t-3)$} & $0.005^{\star *}$ & 0.001 & -0.021 & -0.109 & 0.005 & -0.082 & -0.043 & $-0.324^{*}$ & 0.065 & 0.417 & 0.110 & -0.198 & 0.084 & -0.709 \\
\hline & 0.031 & 0.898 & 0.274 & 0.109 & 0.693 & 0.250 & 0.204 & 0.087 & 0.473 & 0.298 & 0.564 & 0.763 & 0.726 & 0.418 \\
\hline sum coef $[t ; t-3]$ & 0.009 & $0.03^{\text {** }}$ & -0.033 & -0.169 & -0.038 & 0.033 & -0.056 & -0.22 & 0.101 & -0.188 & -0.432 & -1.132 & -0.051 & -0.027 \\
\hline$p$ value of sum test & 0.16 & 0.04 & 0.37 & 0.13 & 0.36 & 0.76 & 0.40 & 0.59 & 0.75 & 0.81 & 0.59 & 0.66 & 0.92 & 0.99 \\
\hline Policy controls & $\mathrm{Y}$ & $\mathrm{Y}$ & $\mathrm{Y}$ & Y & $\mathrm{Y}$ & $\mathrm{Y}$ & $\mathrm{Y}$ & $\mathrm{Y}$ & $\mathrm{Y}$ & $\mathrm{Y}$ & $\mathrm{Y}$ & Y & Y & $\mathrm{Y}$ \\
\hline Other controls & Y & Y & Y & Y & Y & Y & Y & Y & Y & Y & Y & Y & Y & Y \\
\hline Country \& year FE & Y & Y & Y & Y & Y & Y & Y & Y & Y & Y & Y & Y & Y & Y \\
\hline Observations & 2,826 & 2,826 & 2,773 & 2,773 & 2,702 & 2,702 & 2,703 & 2,703 & 2,763 & 2,763 & 2,545 & 2,545 & 2,196 & 2,196 \\
\hline R-squared & 0.051 & 0.053 & 0.121 & 0.121 & 0.031 & 0.031 & 0.111 & 0.111 & 0.105 & 0.106 & 0.119 & 0.161 & 0.142 & 0.136 \\
\hline Number of ifs_code & 51 & 51 & 49 & 49 & 48 & 48 & 48 & 48 & 49 & 49 & 48 & 48 & 48 & 48 \\
\hline
\end{tabular}

Note: ${ }^{*} p<0.10,{ }^{* *} p<0.05,{ }^{* * *} p<0.01$. Standard errors clustered at country level. Italic text displays the sum of the coefficients for all four lags, and the $p$-value of the sum test is displayed below rather that the standard errors as for the other coefficients in this table. 


\title{
Annex B. OECD Working Papers on International Investment
}

\author{
www.oecd.org/investment/working-papers.htm
}

2020

2020/1 The Most Favoured Nation and Non-Discrimination Provisions in International trade law and the OECD Codes of Liberalisation

\section{9}

2019/2 The broad policy toolkit for financial stability: Foundations, fences, and fire doors 2019/1 The determinants of Foreign Direct Investment: Do statutory restrictions matter?

\section{8}

2018/1 Societal benefits and costs of International Investment Agreements: A critical review of aspects and available empirical evidence

\section{7}

2017/5 Adjudicator Compensation Systems and Investor-State Dispute Settlement

2017/4 Have currency-based capital flow management measures curbed international banking flows?

2017/3 Addressing the balance of interests in investment treaties: The limitation of fair and equitable treatment provisions to the minimum standard of treatment under customary international law

2017/2 The balance between investor protection and the right to regulate in investment treaties: A scoping paper

2017/1 Foreign direct investment, corruption and the OECD Anti-Bribery Convention

\section{6}

2016/3 State-to-State dispute settlement and the interpretation of investment treaties

2016/2 Investment policies related to national security

2016/1 The legal framework applicable to joint interpretive agreements of investment treaties

2015

2015/3 Currency-based measures targeting banks - Balancing national regulation of risk and financial openness

2015/2 Investment Treaties over Time - Treaty Practice and Interpretation in a Changing World

2015/1 The Policy Landscape for International Investment by Government-controlled Investors: A Fact Finding Survey

2014

2014/3 Investment Treaties and Shareholder Claims: Analysis of Treaty Practice

2014/2 Investment Treaties and Shareholder Claims for Reflective Loss: Insights from Advanced Systems of Corporate Law 
2014/1 Investment Treaty Law, Sustainable Development and Responsible Business Conduct: A Fact Finding Survey

2013

2013/4 Temporal validity of international investment agreements: a large sample survey of treaty provisions

2013/3 Investment treaties as corporate law: Shareholder claims and issues of consistency

2013/2 Lessons from Investment Policy Reform in Korea 2013/1 China Investment Policy: an Update

2012

2012/3 Investor-state dispute settlement: A scoping paper for the investment policy community

2012/2 Dispute settlement provisions in international investment agreements: A large sample survey

2012/1 Corporate greenhouse gas emission reporting: A stocktaking of government schemes

\section{1}

2011/2 Defining and measuring green FDI: An exploratory review of existing work and evidence

2011/1 Environmental concerns in international investment agreements: a survey

2010

2010/3 OECD's FDI Restrictiveness Index: 2010 Update

2010/2 Foreign state immunity and foreign government controlled investors

$2010 / 1$ Intellectual property rights in international investment agreements

2006

2006/4 OECD's FDI regulatory restrictiveness index: Revision and extension to more economies

2006/3 Interpretation of the Umbrella Clause in Investment Agreements

2006/2 Investor-State Dispute Settlement in Infrastructure Projects

2006/1 Improving the System of Investor-State Dispute Settlement: An Overview

2005

2005/3 Corporate Responsibility Practices of Emerging Market Companies - A Fact-Finding Study

2005/2 Multilateral Influences on the OECD Guidelines for Multinational Enterprises

2005/1 Transparency and Third Party Participation in Investor-State Dispute Settlement Procedures

2004

2004/6 Mobilising Investment for Development: Role of ODA - The 1993-2003 Experience in Vietnam

2004/5 ODA and Investment for Development: What Guidance can be drawn from Investment Climate Scoreboards?

2004/4 Indirect Expropriation and the Right to Regulate in International Investment Law

2004/3 Fair and Equitable Treatment Standard in International Investment Law

2004/2 Most-Favoured-Nation Treatment in International Investment Law

2004/1 Relationships between International Investment Agreements 
2003/2 Business Approaches to Combating Corrupt Practices

2003/1 Incentives-based Competition for Foreign Direct Investment: The Case of Brazil

2002

2002/2 Managing Working Conditions in the Supply Chain: A Fact-Finding Study of Corporate Practices

2002/1 Multinational Enterprises in Situations of Violent Conflict and Widespread Human Rights Abuses

2001

2001/6 Codes of Corporate Conduct: Expanded review of their contents

2001/5 The OECD Guidelines for Multinational Enterprises and other corporate responsibility instruments 2001/4 Public policy and voluntary initiatives: What roles have governments played?

2001/3 Making codes of corporate conduct work: Management control systems and corporate responsibility

2001/2 Corporate Responsibility: Results of a fact-finding mission on private initiatives

2001/1 Private Initiatives for Corporate Responsibility: An Analysis

2000

2000/5 Recent trends, policies and challenges in South East European countries

2000/4 Main determinants and impacts of FDI on China's economy

2000/3 Lithuania: Foreign Direct Investment Impact and Policy Analysis

2000/2 Investment Patterns in a Longer-Term Perspective

2000/1 Bribery and the business sector: Managing the relationship

1999

1999/3 Rules for the Global Economy: Synergies between Voluntary and Binding Approaches

1999/2 Deciphering Codes of Corporate Conduct: A Review of their Contents

1999/1 Southeast Asia: the Role of FDI Policies in Development 1998 1998/1 Survey of OECD work on international investment 